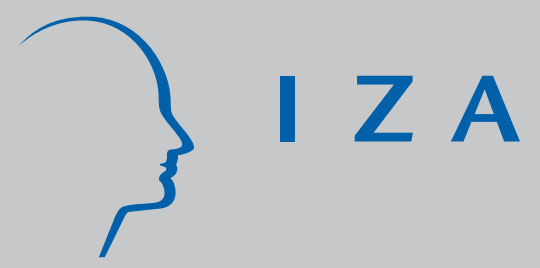

IZA DP No. 66

The Immigrant Welfare Effect:

Take-Up or Eligibility?

\author{
Edward J. Bird \\ Hilke Kayser \\ J oachim R. Frick \\ Gert G. Wagner \\ October 1999
}




\title{
The Immigrant Welfare Effect: Take-Up or Eligibility?
}

\author{
Edward J. Bird \\ University of Rochester \\ Hilke Kayser \\ Hamilton College \\ Joachim R. Frick \\ German Institute for Economic Research \\ Gert G. Wagner \\ European University Viadrina Frankfurt(Oder), \\ German Institute for Economic Research (DIW), \\ Institute for the Study of Labor (IZA), Bonn, \\ Centre for Economic Research (CEPR), London
}

\section{Discussion Paper No. 66 October 1999}

\author{
IZA \\ P.O. Box 7240 \\ D-53072 Bonn \\ Germany \\ Tel.: +49-228-3894-0 \\ Fax: +49-228-3894-210 \\ Email: iza@iza.org
}

This Discussion Paper is issued within the framework of IZA's research area The Welfare State and Labor Markets. Any opinions expressed here are those of the author(s) and not those of the institute. Research disseminated by IZA may include views on policy, but the institute itself takes no institutional policy positions.

The Institute for the Study of Labor (IZA) in Bonn is a local and virtual international research center and a place of communication between science, politics and business. IZA is an independent, nonprofit limited liability company (Gesellschaft mit beschränkter Haftung) supported by the Deutsche Post AG. The center is associated with the University of Bonn and offers a stimulating research environment through its research networks, research support, and visitors and doctoral programs. IZA engages in (i) original and internationally competitive research in all fields of labor economics, (ii) development of policy concepts, and (iii) dissemination of research results and concepts to the interested public. The current research program deals with (1) mobility and flexibility of labor markets, (2) internationalization of labor markets and European integration, (3) the welfare state and labor markets, (4) labor markets in transition, (5) the future of work, (6) project evaluation and (7) general labor economics.

IZA Discussion Papers often represent preliminary work and are circulated to encourage discussion. Citation of such a paper should account for its provisional character. 


\section{ABSTRACT \\ The Immigrant Welfare Effect: Take-Up or Eligibility?}

Are immigrants on welfare because they are more likely to be eligible or because they are more likely to claim benefits for which they are eligible? The answer is politically important, but because most current research on immigration and welfare is based on data from the U.S., the answer is difficult due to the complexities of the transfer system which make eligibility determinations difficult. In Germany, by contrast, eligibility for the main cash transfer program, Sozialhilfe (Social Assistance), is determined by a comparatively simple nation-wide formula. We use data from the German Socio-Economic Panel to test whether immigrants to Germany are more likely than natives to claim welfare benefits for which they are eligible. We find that immigrants are more likely than native Germans to receive welfare, both because immigrants are more likely to be eligible, and because they are more likely, when eligible, to claim their benefits. However, we also find that this greater propensity to take-up benefits is not related to immigrant status per se: when other socio-demographic factors are accounted for in an appropriate manner, immigrant households are no more likely to take up benefits than native households.

JEL Classification: H53, I38, J61

Keywords: Immigration, social assistance, eligibility, take-up

Gert G. Wagner

German Socio Economic Panel Study (GSOEP)

German Institute for Economic Research (DIW)

Königin-Luise-Str. 5

D-14191 Berlin

Germany

Tel.: +4930 89789290

Fax: +493089789 109

Email: gwagner@diw.de 


\section{Introduction}

Political affairs in many developed countries have been affected in recent years by negative sentiment against immigrants. One flashpoint in particular has been a widespread belief that immigrants are more likely to claim benefits under the country's social welfare system than natives, and that therefore immigration represents a significant cost to the taxpayer. This belief is not without a statistical basis. Looking at raw participation rates, Frick, Smeeding and Wagner (1999, Table 5) find that immigrants in Germany are 3.7 times more likely to receive means-tested transfers, and those in the U.S. are 1.5 times more likely. In the U.S., perceptions about the costs of immigration have led to significant social policy changes. The major welfare-reform law passed in August, 1996 (the Personal Responsibility and Work Opportunity Reconciliation Act) denied benefits to legal immigrants under a number of federal programs, and allowed states to be even more stringent. ${ }^{1}$ In Germany, the recent reform of asylum laws (Asylbewerberleistungsgesetz) may have been affected by perceptions that asylum applicants were actually economic refugees seeking a springboard to a better life through Germany's generous social welfare system.

In brief, we find that immigrants are more likely to receive welfare than native citizens. We also find that raw take-up rates are higher among immigrants than native Germans (60 versus 35 percent). However, the differences disappear after controlling for other variables. All else equal, immigrants are no more likely than natives to claim welfare. We suspect that immigrants claim welfare more frequently not because they are immigrants, but because they happen to find themselves more frequently in the kinds of life circumstances that also lead native citizens to claim welfare. There appears to be nothing about being an immigrant per se that leads to greater take-up.

We would argue that our results are broadly informative for debates about immigration in other countries. Although comparable take-up results are not available for 
other countries, we present other statistics that are comparable to other countries, particularly the U.S. In these cases, there is considerable similarity between what we have found and what has been found elsewhere. Germany does not appear to be an odd case along these other dimensions, therefore we infer that Germany's immigrant take-up situation may well be replicated elsewhere. ${ }^{2}$

The paper is structured as follows. Section II below discusses our research question and the literature. Section III gives an overview of the German SA system. Section IV describes our data and methods for determining eligibility. Section V provides descriptive statistics and take-up rates for German natives and immigrants. Section VI presents results from regressions of SA participation on various household characteristics. Section VII concludes.

\section{Research Question and Literature}

More sophisticated empirical analyses of welfare participation do suggest a positive immigrant effect. In the U.S., studies by Blau (1984), Borjas and Trejo (1991), Borjas and Hilton (1996), Hu (1998), and Van Hook and Bean (1998) all suggest that immigrants are more likely to receive welfare. In Germany, a positive immigrant welfare effect is found not only by Frick, Smeeding, and Wagner (1999), but also by Voges, Frick and Büchel (1998), and Riphahn (1998). In Canada, however, results are more mixed. Baker and Benjamin (1995) find that immigrants are less likely to receive benefits, while Siklos and Marr (1998) find they are more likely. Overall, the literature suggests that immigrants seem to participate more frequently in social programs, but that this effect erodes as immigrants assimilate into the native country. ${ }^{3}$

Our paper is motivated by an aspect of immigration that seems to be important for the political discussion, but that the existing research has been unable to address. The research as 
it now stands has explored questions of welfare receipt, while the political issues revolve, we believe, not only around receipt but also take-up: Are immigrants simply more eligible for welfare, or are they more likely to claim welfare given their eligibility? We think the second question is particularly important.

While one can debate whether eligibility really is a matter of personal choice, take-up behavior is more likely to be freely chosen by the individual. A group with high eligibility rates, all else equal, may be considered economically unfortunate or even victimized. A group with high take-up rates, all else equal, is less likely to be granted such sympathies. High take-up rates are likely to be seen as a sign of weak personal or cultural norms against dependency, and thus open the group to more intense stigma (Bird, 1999). Our objective is to test whether there is any empirical basis for such a belief: Is the positive immigrant welfare effect a matter of a different take-up choices, all else equal, or is it simply the result of differences in eligibility and the external circumstances that affect take-up?

While questions like these have been considered important by other researchers in the field, it has proven difficult to generate any solid evidence, simply because eligibility status is unobserved in the data and is very difficult to estimate. Indeed estimating eligibility for even individual U.S. social programs has been the object of entire studies, such as Food Stamps (Tripp, Doyle, and Asher, 1992) and Aid to Families with Dependent Children (Ruggles and Michel, 1987). An additional focus on immigrants has been rare. Hu (1998, p. 727ff) makes an attempt to impute immigrant eligibility and take-up rates for one program, Supplemental Security Income, but the quality of the imputation is negatively affected by data problems: SSI has an asset limit that differs across states, and, although finding the state-level asset limits may not be difficult, the failure of finding data that accurately record household assets especially households at the low end of the income distribution - makes any eligibility determination inaccurate. Borjas and Hilton (1996, p. 596ff) do not directly estimate 
eligibility and take-up, but they do try to identify whether communal networks, which spread information and norms about available benefits, might affect the receipt patterns of U.S. immigrants. The results of both papers suggest that there may be an immigrant take-up effect in addition to the receipt effect. No other research (to our knowledge) tries to address these questions, not even indirectly.

It is important to note that the two studies just mentioned are based on U.S. data, even though U.S. social policy is well-known for the complexities of its eligibility rules. There is a very wide variety of federal and state means-tested programs, offering cash and in-kind assistance on the basis of widely different eligibility criteria. Thus, a direct examination of take-up rates in the U.S. is quite difficult, and, since U.S. studies have been first in the field, this may explain why take-up issues have not been prominent on the research agenda.

This need not be so, however, since social programs in other countries may have eligibility rules simple enough to allow a direct examination of take-up rates. In Germany, for example, one program acts as the predominant national source of means-tested welfare assistance - Sozialhilfe or Social Assistance (SA). While one must not over-emphasize the uniformity of the German SA system (it is affected by a number of quirks and qualifications which will be discussed later), determining eligibility is much easier under SA than under the social assistance systems of most other countries, especially the U.S.

Past studies for Germany have suggested that the take-up of Social Assistance is less than universal among the eligible population. Studies going back to the early 1980s (e.g. Hauser, Cremer-Schäfer, and Nouvertné, 1981; Hartmann, 1985) have suggested that only about half of eligible Germans actually claimed their social assistance benefits. Recent estimates (Hauser and Hübinger, 1993; Neumann and Hertz, 1998) put the non-take-up rate (referred to in the German-language literature as the Dunkelziffer - the 'Dark Number') at 50 to 60 percent. 
As in the U.S., an additional focus on the take-up of immigrants does not exist to the best of our knowledge. However, there is certainly room for the take-up behavior of native Germans and immigrants to differ. In a study comparing households with recent immigrants and households without immigrants or foreigners, for example, Frick et al. (1997, pp. 28-30) analyze welfare receipt and poverty rates. Defining a poverty threshold at 40 percent of median income, they find poverty rates for immigrants to be 4.1 times as high as those for natives. At the same time welfare receipt rates among recent immigrants are only 3.5 times as high. Interpreting poverty rates as an indirect measure of eligibility, this difference provides an indication for different take-up behavior.

Our research strategy, then, comes down to this: We will use data from the German Socio-Economic Panel to make reasonably accurate imputations of SA eligibility and take-up rates for a sample of immigrant and native residents in Germany. ${ }^{4}$ Thus, we provide the most direct measurement, to date, of take-up rates among immigrants and natives in a developed economy within an appropriate econometric framework.

\section{The German Social Assistance System}

Historically, Germany's welfare state has relied heavily on the principle of social insurance rather than means-tested assistance. Social assistance was not very important and it was the responsibility of local governments, as in most countries, but in 1961 a general, national, means-tested assistance program was introduced. Sozialhilfe (Social Assistance, or SA) remains today as the most important means-tested part of the German social welfare system. $^{5}$

Social Assistance is divided into two branches. The most important one is Hilfe zum Lebensunterhalt (HLU) which is the SA system's provision for ongoing monthly payments to households deemed eligible on the basis of their incomes. These support payments make up 
82.5 percent of the system's non-institutional expenditures (not including expenditures on institutionalized clients - see Neuhäuser, 1996, p. 635). ${ }^{6}$ Each Bundesland (federal state) sets an income threshold which represents the minimum income necessary for a single adult individual to maintain a reasonably dignified existence in contemporary society - a mandate laid down by the German constitution. Variations across the states are small: In 1996, the standard one-person rate for SA payments ranged from DM $522(\approx \$ 300)$ in the western states of Hesse and Baden-Wurttemberg to DM $504(\approx 285)$ in the eastern states MecklenburgWest-Pomerania, Saxony, and Thuringia.

This adult-equivalent minimum income is adjusted for families according to a fixed equivalence scale, so that the standard rate for a single adult is increased by a certain fraction for additional family members. A second adult increases the amount paid by 80 percent; an infant adds 50 percent. For the most part, the HLU payments are made in cash, and they supplement the family's income up to the threshold, plus housing costs. ${ }^{7}$ One-time supplements are available to help pay for special needs, such as a telephone connection. Additional regular payments are also available for people in ongoing special circumstances, such as old age, permanent disability, pregnancy, or lone parenthood; in general these extra payments are determined by fairly firm rules (e.g. an extra 20 percent is available for single parents with one child under age 7). Eligibility is determined, and payments are distributed, by local governments and semi-public charity organizations.

It is important to notice that, even though calculating the exact level of HLU payments can be quite complicated, depending on a household's specific income components and wealth situation, determining basic eligibility is much less complicated for most households. Simply, a household is HLU-eligible if its income falls below the HLU threshold, with some modifications. The eligibility modifications are basically fixed by administrative practice, and can be obtained from officials in the German social welfare system. Thus while we would not 
be comfortable claiming that our eligibility determinations are perfect, we do feel that they are quite accurate relative to the eligibility judgments which might be made for programs in other countries. ${ }^{8}$ This is certainly true for the U.S., where it is probably misleading to refer to the totality of means-tested transfers as a 'system'. Instead, the assistance available to the poor has always been a haphazard combination of local, state, and federal programs, in cash and in kind, with a broad variety of eligibility rules. Yet it is in the U.S. that most recent research on immigrants and welfare has been conducted. By contrast, the relative simplicity of the German HLU system allows a unique opportunity to explore not just the participation of immigrants, but their eligibility and take-up as well.

\section{Data and Methods}

1. Data source and the eligibility assignment procedure

We use data from the German Socio-Economic Panel (SOEP), a repeated sample of German households begun in 1984 in the former West Germany, and extended in 1990 to include the new eastern federal states. Certain aspects of the SOEP, and recent additions to it, make it especially valuable for a study of immigration. The original West-German subsample included an oversample of foreign workers (Gastarbeiter), who mainly immigrated during the 1960s and early 1970s. Of major importance for our study, however, is the fact that in 1995 the SOEP added a special sub-sample of immigrants to West-Germany who entered the country after 1984, and thus had no chance to be included in the original sample (Burkhauser, Kreyenfeld, and Wagner, 1996). This addition encompasses the massive influx of persons from Eastern Europe after the fall of the Berlin Wall in 1989 (including the Aussiedler ethnic germans from countries other than Germany). Evidence suggests that failure to account for these demographic flows, or the much milder earlier ones, can affect the results of empirical studies. ${ }^{9}$ 
The SOEP variables cover the economic status of the individuals and households in the sample, as well as their social and demographic characteristics and a number of subjective satisfaction indices. We also observe whether any household members were born in a foreign country, as well as the year of immigration and the country of origin.

We take a cross-section from the 1996 wave of the panel and construct a data set using the household as the unit of observation (6,567 cases unweighted). Applying appropriate population weights, which also control for potential attrition in previous waves, these cases form a representative sample of all non-institutionalized households living in Germany in early 1996. For each household in our data, we obtain information about the age, gender, marital status, and education of the head; the household's composition; its residential location; and its income (including the earnings, the non-labor income, and the transfer income of all household members) in the month of the interview.

We will explore two indicator variables. The first is an indicator of whether the family actually obtained assistance for life support (HLU) in the month of interview. This variable indicates welfare receipt and has been studied often in the literature. The results for this variable will allow us to compare our findings to those of others, to see whether our broader conclusions from these data might be applicable elsewhere.

The second variable, unique to our study, is whether the family was eligible for HLU. This is calculated within our data according to the rules of SA system. The algorithm for the calculation needs to take into account a given household's size and composition as well as special living conditions of this household and the individuals living therein.

The starting point for the algorithm is each individual's base weight, which assigns a value of 1.0 to the head of the household and weights varying from 0.5 to 0.9 to additional household members according to age. ${ }^{10}$ An individual's base weight may be increased due to additional needs caused by "special circumstances" (Mehrbedarfszuschläge) based upon age, 
disability status, household composition of lone parent families and pregnancy. ${ }^{11}$ The household weight is the sum of the individual weights of all household members (individual base weights plus weights for additional needs). The household weight is multiplied by an income threshold which represents the minimum income that is deemed essential for a single adult in the household's federal state (Eckregelsatz). Across states, this need threshold in 1996 ranged from about DM 504 in the Eastern states to about DM 522 in the Western states. ${ }^{12}$ Then costs of housing, heating, and warm water are added, with the total being the household's overall economic need. ${ }^{13}$

The formula for calculating need is as follows:

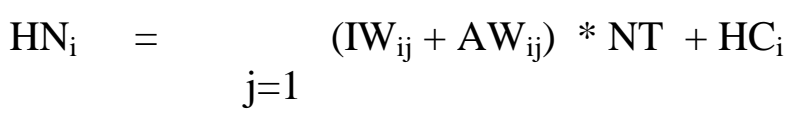

where

$$
\begin{array}{lll}
\mathrm{HN}_{\mathrm{i}} & = & \text { household i's total economic need } \\
\mathrm{n} & = & \text { number of household members } \\
\mathrm{IW}_{\mathrm{ij}} & = & \text { Individual } \mathrm{j} \text { 's base weight } \\
\mathrm{AW}_{\mathrm{ij}}= & \text { weights for additional need (Mehrbedarfszuschläge) } \\
\mathrm{NT} & = & \text { state-specific need threshold (Eckregelsatz, approx. \$300) } \\
\mathrm{HC} & = & \text { housing costs }
\end{array}
$$

To determine eligibility, current household income is compared to household needs. The income measure used for this comparison is the actual current household income adjusted for certain deductible expenditures (Absetzbeträge) in case of employment as well as for some transfer payments. ${ }^{14}$ If the household's adjusted income is below the overall household's needs, the household is considered eligible for HLU, i.e.:
(2) $\quad \mathrm{HLU}_{\mathrm{i}}=1$
if $\mathrm{HN}_{\mathrm{i}}>\mathrm{HH}$-Income (minus deductions) 


$$
\mathrm{HLU}_{\mathrm{i}}=0 \quad \text { if } \mathrm{HN}_{\mathrm{i}} \leq \mathrm{HH} \text {-Income (minus deductions). }
$$

We apply this eligibility method to all the households in our sample, including native Germans and immigrants. We define immigrant households as those households with an immigrant head and spouse. ${ }^{15}$ We will also look at households with different compositions, however. We define 'native' households as households in which neither the head nor the spouse is an immigrant, while a mixed household has one immigrant and one native as head or spouse. An 'immigrant' is defined as a person who was born in a country other than Germany. Thus, our sample of immigrants includes Ethnic Germans such as the Russian Volga-Deutsche. German immigration and asylum laws have made strict distinctions between immigrants of German ethnic background and other immigrants, but we have chosen not to make this distinction. We can take account of the ethnicity of immigrants by using the appropriate controls in regressions.

Being aware that income measurements can contain errors, we take one further step to be conservative about our eligibility assignments: we assign eligibility to households whose needs are 1.05 times higher than income. Eventually we will examine the group of HLUeligible households as a separate sample, and inflating the needs threshold by 5 percent gives us greater confidence that this sample of HLU-eligible households contains no households that are not actually eligible for the program.

\section{Econometric Issues.}

Having estimated eligibility for HLU, we are able to perform two kinds of regression analysis. The first takes the entire sample of respondents living in Germany and conducts probit regressions of HLU receipt on household characteristics. The second restricts the 
sample to HLU eligible households, and conducts probit regressions of take-up on household characteristics.

In restricting the sample by eligibility status, we may generate bias in the coefficients. To see this, suppose the regression of interest is

(3) $\quad T=\alpha+\beta_{1} I+\beta_{2} X+\beta_{3} Y+\varepsilon$

where $\mathrm{T}$ is take-up, $\mathrm{Y}$ is income, $\mathrm{I}$ indicates the respondent is an immigrant, $\mathrm{X}$ is a vector of other household characteristics, and $\varepsilon$ is an error term. Because we only include HLU-eligible households in the sample, we are effectively selecting the sample on income. This has two implications. First, failure to include $\mathrm{Y}$ in the regression generates correlation between I and $\varepsilon$ and between $X$ and $\varepsilon$, creating (downward) bias in $\beta_{1}$ and $\beta_{2}$. Therefore, we should always include $\mathrm{Y}$ in our take-up regressions. Second, measurement error in $\mathrm{Y}$ will affect not only the coefficient on $\mathrm{Y}, \beta_{3}$, but also all the other coefficients because the error affects selection into the sample. Moreover, if decisions regarding income and take-up are made simultaneously, Y is endogenous and would require a separate equation. For all those reasons it is necessary to instrument for income in our regressions. We use indicators of industry and occupations and parents' education as the identifying variables in our instrumenting equation. ${ }^{16}$

\section{Descriptive Statistics}

Table 1 presents weighted estimates of the number of households in Germany, broken down by immigrant status and HLU receipt. The line of totals shows that, of the 37 million German households, 2.84 million (7.6 percent) had an immigrant head and spouse (if spouse is present); this is the group defined as 'immigrant households'. The mixed households 
include 737,000 households with a native head and an immigrant spouse, and 660,000 with an immigrant head and a native spouse. The remaining 33 million households had native heads and native spouses (if spouse is present).

Among all families, 5.7 percent are eligible for HLU according to our assignment procedure. Only 2.3 percent indicate that they actually receive HLU payments, meaning that 59.6 percent of the eligible population fails to claim an HLU benefit for which it is eligible. This estimate of the non-take-up rate (Dunkelziffer) is within the range found for Germany by other researchers (Hauser and Hübinger, 1993; Neumann and Hertz, 1998). More interesting for our purposes is the contrast between natives and immigrants: 40.0 percent of eligible immigrant households fail to take up their HLU benefits while 65.3 percent of all-native households do so. Moreover, 14.5 percent of immigrant households are eligible while only 5.0 percent of native households are. These two differences lead to large differences in receipt: Some 8.7 percent of immigrant households receive HLU while only 1.8 percent of all-native households do so. Thus, immigrants to Germany are 4.9 times more likely to receive assistance, a ratio that is higher than that found in the U.S. (Borjas and Hilton, 1996).

How much of this is eligibility? If all eligible households claimed their benefits, immigrants would be only $14.5 / 5.0=2.9$ times more likely to be receiving HLU. Therefore, the greater propensity of eligible immigrants to claim benefits accounts for (4.9-2.9)/4.9 $=41$ percent of the receipt difference, while differences in eligibility account for the remaining 59 percent.

\section{Regression Statistics}

That immigrants are more likely to take-up HLU benefits, however, does not imply that it is immigration per se that leads to this behavioral difference. The question is, are eligible immigrants more likely to claim welfare than eligible native citizens with similar 
characteristics, or does the positive immigrant take-up effect disappear once a household's situation is accounted for?

To explore this question, we ran a number of probit regressions in which the dependent variable is defined as a 1 if the household receives HLU and a 0 if not. Table 2 provides some descriptive statistics of our regression variables. Note that 1,008 of the 6,567 cases in our sample are immigrant households, a sufficient number to observe reliable regression patterns across the groups.

To begin, we focus on simple participation. Table 3 presents a series of regressions in which the dependent variable is just receipt of HLU, without considering take-up. ${ }^{17}$ Regression 1a just repeats the message of Table 1, showing that immigrant households are more likely to receive HLU. Regression $1 \mathrm{~b}$ distinguishes mixed households from the allnative households, showing that variations on immigrant-head status do not change the likelihood of participation very much. $2 \mathrm{a}$ and $2 \mathrm{~b}$ repeat these regressions but add information on household structure; immigrant-headed households are still significantly more likely to participate. The remaining columns (3 and 4) show that the positive immigrant participation effect persists after controlling for the head's age, sex, and education, and the location of the household. As has been found by others (notably Borjas and Hilton, 1996), the positive immigrant welfare participation effect is reduced, but not eliminated, after controlling for the characteristics of the household.

To focus on take-up behavior, in Table 4 we retain only HLU-eligible households in the sample, which comes to 365 raw observations in our data. This smaller sample size will of course generate higher standard errors on the coefficients than in Table 3. On the other hand, the sample is not vanishingly small, and in fact there seems to be enough variation in the data to obtain meaningful results for the variables of interest. 
In Table 4 we present a number of probit regressions with take-up as the dependent variable $(1=$ take-up, $0=$ non-take-up). The first column shows that when only income is controlled for, immigrants are more likely than natives to take-up benefits, although the effect is not statistically significant. The second column suggests that this result is not affected by how one defines the immigrant household; breaking out mixed households from the native households has little effect on the coefficients. The remaining columns in the table add more controls to the regression. While income, age, and family structure variables have large and statistically significant coefficients, in no case are the immigrant indicators statistically significant. Indeed, with a full set of controls (columns $4 \mathrm{a}$ and $4 \mathrm{~b}$ ), the coefficient on immigrant status has a negative sign - though it is statistically insignificant - indicating that native Germans are more likely to take up benefits than immigrants. The higher raw rate of take-up by immigrants thus seems to be explained by the concentration of take-up inducing characteristics in the immigrant population, and not by immigrant status per se.

In order to test whether attrition may affect the results in our longitudinal sample we apply a Heckman procedure. The waves' staying probabilities that are provided in the data are based on results from logistic regressions using household information from the previous and the current year and can be combined to obtain household-specific probabilities of still being part of the survey in 1996. Thus, they are likely to capture much of the demographic flows that affect welfare receipt in the work by Riphahn (1998). We use the combined staying probabilities to construct an inverse Mill's ratio which is plugged into the regression equation. The coefficient on this selection correction term are very small (-.003 to -.014) and statistically insignificant across all specifications. The other regression coefficients are almost identical to those from an estimation without the inverse Mill's ratio. Thus, we find no evidence that differences in attrition affect the results on welfare take-up in our sample. ${ }^{18}$ 
The pattern of the family structure variables is interesting in itself (see column $4 \mathrm{a}$ in table 4). Among the eligible households, lone parents are less likely than others to claim benefits ( $\beta=-1.004$ ), despite the probability that these families are more needy than others. (The omitted category is two-adult, no child families.) It should be remembered, however, that need is already accounted for by the presence of income and child variables in the regressions. Also, if the single parent is not married $(B=1.046)$, he or she will be slightly more likely to claim benefits than two-adult, no-child families, and much more likely than single adult families. ${ }^{19}$

In substantive terms, the effect of being an immigrant is moderate, neither small nor large. In Table 5 we show the result of predicting the probability of take-up using the coefficients in regression $4 \mathrm{a}$ of Table 4 . With all independent variables set to their sample mean, and with the immigrant variable set to 0 , the predicted probability of take-up is 41.9 percent. With immigrant set to 1 , the predicted take-up rate is somewhat lower, 37.4 percent. This effect is roughly comparable to a DM 100 increase in a family's monthly income, which lowers the predicted take-up rate from 40.5 percent to 38.1 percent.

Table 6 returns to the probit method but alters the set of independent variables. In the first column, immigrants are distinguished by whether they have significant sources of wealth. ${ }^{20}$ Up to a certain amount, wealth does not affect eligibility and thus would be a buffer against poverty. High-wealth households would therefore be less likely to claim benefits. We have three binary variables: immigrant with wealth, immigrant without wealth, and native without wealth; coefficients indicate the probability of claiming benefits relative to native households with wealth. Immigrant and native households without wealth are more likely to claim benefits than natives with wealth, but the effects are about the same (0.131 vs. 0.231$)$ and not statistically significant. Low-wealth immigrants do not seem to have greatly different take-up behavior from natives. $^{21}$ 
Column 2 of Table 6 adds indicators of federal state of residence (rather than region), and subjective measures of well-being and attitudes. The coefficient on immigrant status is again small and statistically insignificant. Column 3 takes the immigrant status variable and interacts it with answers to questions about assimilation that were asked only of foreigners. The immigrant-status coefficient remains negative and not statistically significant. This base is affected by answers to the various questions, however. For example, immigrants were asked whether the language used at home is mainly German. For those who said 'yes,' the likelihood coefficient equals the base immigrant status coefficient plus the coefficient on the home-language variable, or $-0.411-0.016=-0.427$. The one statistically significant effect involves those immigrants who express a desire to remain in Germany; for these the likelihood coefficient is $-0.411+0.526=0.115$. This means that immigrants wishing to return home are less likely to take up HLU benefits, while those wishing to stay are more likely.

Finally, Table 7 explores effects of country of origin and entry cohort. Immigrants from the EU are the least likely to claim benefits, while those from regions other than those listed (e.g. the developing world) are most likely. As for entry cohorts, entrants since 1991 are more likely to claim benefits, while entrants from 1976 to 1990 are less likely. Although none of these effects is statistically significant, they do roughly match patterns found in previous literature.

Overall, the finding that immigrant status per se does not strongly affect take-up rates seems to be fairly robust in the data, and does not change across all these empirical variations. 


\section{Conclusion}

The main proposition in which we were interested at the start was whether immigrants are more likely than natives to claim benefits for which they are eligible. Some such belief, we feel, may be at the heart of some of the anti-immigrant sentiment one observes in various countries in debates about the costs of welfare. In our data, however, it appears that eligible immigrants are not substantially more likely to claim benefits than eligible and observationally similar natives. While the raw take-up rates of immigrants are higher than the take-up rates of Germans, this is because immigrants are more likely to be in the circumstances that would lead any household - German or immigrant - to claim benefits more frequently. Thus, being an immigrant per se does not appear to explain much of the difference in take-up rates; the difference seems to come from differing patterns of income, household structure, and age between immigrants and natives. 


\section{References}

Baker, Michael and Dwayne Benjamin (1995), "The Receipt of Transfer Payments by Immigrants to Canada," Journal of Human Resources 30(4), pp. 650-676.

Bird, Edward J. (1999), "Can Welfare Policy Make Use of Social Norms?" Rationality and Society, forthcoming.

Blau, Francine D. (1984), "The Use of Transfer Payments by Immigrants," Industrial and Labor Relations Review, 37(2), pp. 222-239.

Borjas, George J. and Stephen J. Trejo (1991), "Immigrant Participation in the Welfare System," Industrial and Labor Relations Review, 44(2), pp. 195-211.

Borjas, George J. and Lynette Hilton (1996), "Immigration and the Welfare State: Immigrant Participation in Means-tested Entitlement Programs," Quarterly Journal of Economics, 111(2), pp. 575-604.

Bundesministerium für Arbeit und Sozialordnung (1990), Übersicht über die Soziale Sicherheit, Bonn.

Burkhauser, Richard V., Michaela Kreyenfeld and Gert G. Wagner (1996), "The Immigrant Sample of the German Socio-Economic Panel," Syracuse: Cross-National Studies in Aging Program Project No. 29.

Frick, Joachim R., Timothy M. Smeeding, and Gert G. Wagner (1999), "Immigrants in Two Modern Nations: Characteristics of the Foreign and Native Born Populations in Germany and the United States," Vierteljahrshefte zur Wirtschaftsforschung, German Institute for Economic Research, Berlin, 68(2), pp. 297-307. 
Frick, Joachim R., Felix Büchel, Peter Krause, and Gert G. Wagner (1997), "Immigration has Increased Income Inequality and Poverty in Germany Slightly," Economic Bulletin, 34(2), pp. 25-32.

Hartmann, Helmut (1985), "Armut trotz Sozialhilfe. Zur Nichtinanspruchnahme von Sozialhilfe in der Bundesrepublik. " in Stephan Leibfried and Florian Tennstedt (eds.), Politik der Armut und Die Spaltung des Sozialstaats, Frankfurt a.M.: Suhrkamp, pp. 169-189.

Hauser, Richard, Helga Cremer-Schäfer, and Udo Nouvertné (1981), Armut, Niedrigeinkommen und Unterversorgung in der Bundesrepublik Deutschland Bestandsaufnahme und sozialpolitische Perspektiven, Frankfurt/Main: Campus Verlag.

Hauser, Richard and Werner Hübinger (1993), Arme unter uns, Teil 1: Ergebnisse und Konsequenzen der Caritas-Armutsuntersuchung, Freiburg: Deutscher Caritasverband. Hu, Wei-Yin (1998), "Elderly Immigrants on Welfare," Journal of Human Resources, 33(3), Summer, pp. 711-741.

Neuhäuser, Jenny (1996), "Sozialhilfe und Leistungen an Asylbewerber 1994," Wirtschaft und Statistik, No. 10, , pp. 663-641.

Neumann, Udo and Markus Hertz (1998), "Verdeckte Armut in Deutschland," Forschungsbericht im Auftrag der Friedrich-Ebert-Stiftung, Frankfurt: Institut für Sozialberichterstattung und Lebenslagenforschung.

Passel, Jeffrey S., Rebecca L. Clark, and Michael Fix (1997), "Naturalization and Other Current Issues in U.S. Immigration: Intersection of Data and Policy," Proceedings of the American Statistical Association, 1997 Section on Government Statistics and Section on Social Statistics, pp 1-10. 
Riphahn, Regina T. (1998), "Immigrant Participation in the German Welfare Program," Finanzarchiv N.F., 55 (2), pp. 163-185.

Ruggles, Patricia and Richard C. Michel (1987), "Participation Rates in the Aid to Families with Dependent Children Program: Trends for 1967 Through 1984," Washington, D.C.: The Urban Institute.

Siklos, Pierre L. and William L. Marr (1998), "The Unemployment Insurance Compensation Experience of Immigrants in Canada, 1980-1988," Journal of Population Economics, 11, pp. $127-147$.

Tripp, Carole, Pat Doyle and Andrew Asher (1992), Trends in Food Stamp Participation Rates: 1976 to 1990, Washington: Food and Nutrition Service, U.S. Department of Agriculture.

Van Hook, Jennifer V.W. and Frank D. Bean (1998), "Welfare Reform and Supplemental Security Income Receipt Among Immigrants in the United States," in Hermann Kurthen, Jürgen Fijalkowski, and Gert G. Wagner (eds.), Immigration, Citizenship, and the Welfare State in Germany and the United States: Immigrant Incorporation, Stamford: JAI Press, pp. 139-157.

Voges, Wolfgang, Joachim Frick, and Felix Büchel (1998), "The Integration of Immigrants Into West German Society: The Impact of Social Assistance," in Hermann Kurthen, Jürgen Fijalkowski, and Gert G. Wagner (eds.), Immigration, Citizenship, and the Welfare State in Germany and the United States: Immigrant Incorporation, Stamford: JAI Press, pp. 159-174.

Wagner, Gert G., Richard V. Burkhauser, and Friederike Behringer (1993), "The English Language Public Use File of the German Socio-Economic Panel," Journal of Human Resources 28(2), pp. 429-33. 
Zimmermann, Klaus F. (1995), "Tackling the European Migration Problem", Journal of Economic Perspectives, 9 (2), pp. 45-62.

Zimmermann, Klaus F. (1998), "Immigration und Arbeitsmarkt: Eine ökonomische Perspektive", IZA Discussion Paper No. 7, Bonn. 
Table 1: $\quad$ Eligibility for and Receipt of Social Assistance (HLU) by Immigrant Status 1996 (in 1000 households, percent of total in parenthesis)

\begin{tabular}{|c|c|c|c|c|c|}
\hline & $\begin{array}{c}\text { All } \\
\text { Families }\end{array}$ & $\begin{array}{c}\text { All } \\
\text { Native } \\
\text { Household }\end{array}$ & $\begin{array}{c}\text { All } \\
\text { Immigrant } \\
\text { Household }\end{array}$ & $\begin{array}{c}\text { Native } \\
\text { Head, } \\
\text { Immigrant } \\
\text { Spouse }\end{array}$ & $\begin{array}{c}\text { Immigrant } \\
\text { Head, } \\
\text { Native } \\
\text { Spouse }\end{array}$ \\
\hline \multirow[t]{2}{*}{ - Not eligible for HLU } & 35,146 & 31,369 & 2,430 & 710 & 637 \\
\hline & $(94.3)$ & $(95.0)$ & $(85.5)$ & $(96.4)$ & $(96.5)$ \\
\hline \multirow[t]{2}{*}{ Eligible for HLU } & 2,115 & 1,631 & 410 & 26 & 23 \\
\hline & $(5.7)$ & $(5.0)$ & $(14.5)$ & (3.6) & $(3.5)$ \\
\hline \multirow{2}{*}{ - HLU receipt } & 854 & 565 & 246 & 13 & 5 \\
\hline & $(2.3)$ & $(1.8)$ & (8.7) & $(1.8)$ & $(0.8)$ \\
\hline \multirow{2}{*}{ · No HLU receipt } & 1,261 & 1,066 & 164 & 13 & 18 \\
\hline & $(3.4)$ & $(3.2)$ & $(5.8)$ & $(1.8)$ & $(2.7)$ \\
\hline Total & 37,262 & 33,024 & 2,841 & 737 & 660 \\
\hline Non-take-up rate of $\mathrm{HLU}^{a}$ & 59.6 & 65.3 & 40.0 & 50.0 & 78.3 \\
\hline
\end{tabular}

a Households not receiving HLU as a percentage of all eligible households (Dunkelziffer).

Source: SOEP 1996, Authors' calculations, weighted. 
Table 2: $\quad$ Descriptive Statistics for Immigrant and Native Households

\begin{tabular}{|c|c|c|c|c|c|c|c|c|}
\hline \multirow[t]{2}{*}{ Variable } & \multicolumn{2}{|c|}{ Native Households } & \multicolumn{2}{|c|}{$\begin{array}{l}\text { Immigrant } \\
\text { Household }\end{array}$} & \multicolumn{2}{|c|}{$\begin{array}{l}\text { Native Head and } \\
\text { Immigrant Spouse }\end{array}$} & \multicolumn{2}{|c|}{$\begin{array}{c}\text { Native Spouse and } \\
\text { Immigrant Head }\end{array}$} \\
\hline & Mean & $\begin{array}{l}\text { Standard } \\
\text { deviation }\end{array}$ & Mean & $\begin{array}{l}\text { Standard } \\
\text { Deviation }\end{array}$ & Mean & $\begin{array}{l}\text { Standard } \\
\text { Deviation }\end{array}$ & Mean & $\begin{array}{c}\text { Standard } \\
\text { Deviation }\end{array}$ \\
\hline Receiving Social Assistance (HLU) & 0.018 & 0.132 & 0.087 & 0.281 & 0.018 & 0.134 & 0.008 & 0.089 \\
\hline Eligible for HLU & 0.050 & 0.218 & 0.145 & 0.352 & 0.036 & 0.187 & 0.035 & 0.183 \\
\hline Household size & 2.20 & 1.21 & 2.87 & 1.53 & 2.75 & 0.98 & 3.26 & 1.43 \\
\hline Generated household income & 3900 & 2363 & 3600 & 2152 & 4564 & 1859 & 5562 & 2618 \\
\hline Income relevant for HLU eligibility & 3662 & 2325 & 3290 & 2160 & 4298 & 1813 & 5279 & 2590 \\
\hline Number of children age $<4$ & 0.083 & 0.297 & 0.108 & 0.332 & 0.115 & 0.322 & 0.222 & 0.47 \\
\hline Number of children age $4-6$ & 0.082 & 0.306 & 0.144 & 0.391 & 0.183 & 0.442 & 0.21 & 0.419 \\
\hline Number of children age 7-11 & 0.138 & 0.416 & 0.246 & 0.536 & 0.166 & 0.439 & 0.373 & 0.806 \\
\hline Number of children age $12-16$ & 0.112 & 0.374 & 0.24 & 0.562 & 0.113 & 0.353 & 0.198 & 0.47 \\
\hline Age of the household head & 49.9 & 18.1 & 46.3 & 15.6 & 46.1 & 14.1 & 45.8 & 12.9 \\
\hline Male head & 0.610 & 0.488 & 0.722 & 0.448 & 0.651 & 0.477 & 0.69 & 0.462 \\
\hline Head without secondary education & 0.156 & 0.363 & 0.483 & 0.500 & 0.09 & 0.287 & 0.192 & 0.394 \\
\hline Head with secondary education & 0.558 & 0.497 & 0.325 & 0.468 & 0.498 & 0.500 & 0.483 & 0.500 \\
\hline Head with post-secondary education & 0.285 & 0.452 & 0.191 & 0.393 & 0.412 & 0.492 & 0.325 & 0.468 \\
\hline head employed full time & 0.546 & 0.498 & 0.597 & 0.491 & 0.698 & 0.459 & 0.644 & 0.479 \\
\hline head employed part time & 0.059 & 0.236 & 0.041 & 0.198 & 0.045 & 0.207 & 0.083 & 0.275 \\
\hline head unemployed & 0.051 & 0.220 & 0.099 & 0.299 & 0.027 & 0.163 & 0.068 & 0.251 \\
\hline head not in the labor force & 0.058 & 0.234 & 0.069 & 0.253 & 0.029 & 0.169 & 0.103 & 0.304 \\
\hline head retired & 0.293 & 0.455 & 0.206 & 0.404 & 0.201 & 0.401 & 0.127 & 0.333 \\
\hline household living in the North & 0.201 & 0.400 & 0.198 & 0.399 & 0.168 & 0.374 & 0.091 & 0.288 \\
\hline household living in the South & 0.257 & 0.437 & 0.296 & 0.456 & 0.397 & 0.489 & 0.455 & 0.498 \\
\hline household living in the East & 0.333 & 0.407 & 0.021 & 0.143 & 0.074 & 0.262 & 0.097 & 0.296 \\
\hline households living in the West & 0.210 & 0.471 & 0.485 & 0.500 & 0.361 & 0.480 & 0.357 & 0.479 \\
\hline households owns apartment/house & 0.406 & 0.491 & 0.158 & 0.365 & 0.366 & 0.482 & 0.601 & 0.490 \\
\hline $\begin{array}{l}\text { household lives in larger } \\
\text { metropolitan area }\end{array}$ & 0.175 & 0.380 & 0.271 & 0.444 & 0.185 & 0.389 & 0.162 & 0.369 \\
\hline households lives in rural setting & 0.405 & 0.491 & 0.278 & 0.448 & 0.358 & 0.479 & 0.385 & 0.487 \\
\hline Observations & & 5224 & & 1008 & & 158 & & 177 \\
\hline
\end{tabular}

Source: SOEP 1996, Authors' calculations 
Table 3: $\quad$ Social Assistance Receipt (Probit with HLU=0, 1; standard errors in parentheses)

\begin{tabular}{|c|c|c|c|c|c|c|c|c|}
\hline Variable & $1 \mathrm{a}$ & $1 b$ & $2 \mathrm{a}$ & $2 b$ & $3 a$ & $3 b$ & $4 \mathrm{a}$ & $4 \mathrm{~b}$ \\
\hline Intercept & $\begin{array}{l}-2.085 \\
(.040)\end{array}$ & $\begin{array}{l}-2.088 \\
(.041)\end{array}$ & $\begin{array}{l}-2.554 \\
(.129)\end{array}$ & $\begin{array}{l}-2.593 \\
(.134)\end{array}$ & $\begin{array}{l}-1.460 \\
(.359)\end{array}$ & $\begin{array}{l}-1.656 \\
(.359)\end{array}$ & $\begin{array}{l}-2.560 \\
(.408)\end{array}$ & $\begin{array}{l}-2.580 \\
(.410)\end{array}$ \\
\hline Immigrant household & $\begin{array}{l}0.501 \\
(.075)\end{array}$ & $\begin{array}{l}0.504 \\
(.076)\end{array}$ & $\begin{array}{l}0.637 \\
(.087)\end{array}$ & $\begin{array}{l}0.656 \\
(.088)\end{array}$ & $\begin{array}{l}0.436 \\
(.096)\end{array}$ & $\begin{array}{l}0.456 \\
(.098)\end{array}$ & $\begin{array}{l}0.301 \\
(.103)\end{array}$ & $\begin{array}{c}0.32 \\
(.106)\end{array}$ \\
\hline $\begin{array}{l}\text { Immigrant head, native } \\
\text { spouse }\end{array}$ & $\begin{array}{l}--- \\
---\end{array}$ & $\begin{array}{l}0.086 \\
(.238)\end{array}$ & --- & $\begin{array}{l}0.386 \\
(.217)\end{array}$ & $\begin{array}{l}-- \\
---\end{array}$ & $\begin{array}{l}0.242 \\
(.227)\end{array}$ & --- & $\begin{array}{l}0.216 \\
(.231)\end{array}$ \\
\hline $\begin{array}{l}\text { Native head, immigrant } \\
\text { spouse }\end{array}$ & -- & $\begin{array}{l}0.013 \\
(.238)\end{array}$ & --- & $\begin{array}{l}0.032 \\
(.293)\end{array}$ & --- & $\begin{array}{l}0.065 \\
(.311)\end{array}$ & --- & $\begin{array}{l}-0.016 \\
(.323)\end{array}$ \\
\hline Number of children $0-3$ & --- & --- & $\begin{array}{l}0.748 \\
(.090)\end{array}$ & $\begin{array}{l}0.746 \\
(.090)\end{array}$ & $\begin{array}{l}0.690 \\
(.095)\end{array}$ & $\begin{array}{l}0.688 \\
(.095)\end{array}$ & $\begin{array}{l}0.694 \\
(.099)\end{array}$ & $\begin{array}{l}0.694 \\
(.099)\end{array}$ \\
\hline Number of children 4-6 & --- & --- & $\begin{array}{l}0.223 \\
(.100)\end{array}$ & $\begin{array}{l}0.220 \\
(.100)\end{array}$ & $\begin{array}{l}0.190 \\
(.105)\end{array}$ & $\begin{array}{l}0.188 \\
(.105)\end{array}$ & $\begin{array}{l}0.207 \\
(.109)\end{array}$ & $\begin{array}{l}0.207 \\
(.109)\end{array}$ \\
\hline Number of children $7-16$ & -- & -- & $\begin{array}{l}0.278 \\
(.050)\end{array}$ & $\begin{array}{l}0.279 \\
(.050)\end{array}$ & $\begin{array}{l}0.295 \\
(.052)\end{array}$ & $\begin{array}{l}0.296 \\
(.052)\end{array}$ & $\begin{array}{l}0.317 \\
(.054)\end{array}$ & $\begin{array}{l}0.319 \\
(.054)\end{array}$ \\
\hline Single-adult household & -- & -- & $\begin{array}{l}-0.163 \\
(.133)\end{array}$ & $\begin{array}{l}-0.139 \\
(.135)\end{array}$ & $\begin{array}{l}-0.179 \\
(.143)\end{array}$ & $\begin{array}{l}-0.163 \\
(.144)\end{array}$ & $\begin{array}{l}-0.236 \\
(.146)\end{array}$ & $\begin{array}{l}-0.224 \\
(.148)\end{array}$ \\
\hline Single adult with children & --- & --- & $\begin{array}{l}0.216 \\
(.156)\end{array}$ & $\begin{array}{l}0.239 \\
(.158)\end{array}$ & $\begin{array}{l}0.249 \\
(.164)\end{array}$ & $\begin{array}{l}0.264 \\
(.165)\end{array}$ & $\begin{array}{l}0.252 \\
(.169)\end{array}$ & $\begin{array}{l}0.261 \\
(.170)\end{array}$ \\
\hline Several adults with children & -- & -- & $\begin{array}{l}-0.109 \\
(.137)\end{array}$ & $\begin{array}{l}-0.090 \\
(.138)\end{array}$ & $\begin{array}{l}-0.137 \\
(.142)\end{array}$ & $\begin{array}{l}-0.125 \\
(.143)\end{array}$ & $\begin{array}{l}-0.095 \\
(.148)\end{array}$ & $\begin{array}{c}-0.088 \\
(.148)\end{array}$ \\
\hline Not married & --- & --- & $\begin{array}{l}0.729 \\
(.115)\end{array}$ & $\begin{array}{l}0.741 \\
(.116)\end{array}$ & $\begin{array}{l}0.627 \\
(.125)\end{array}$ & $\begin{array}{l}0.638 \\
(.126)\end{array}$ & $\begin{array}{l}0.614 \\
(.129)\end{array}$ & $\begin{array}{l}0.624 \\
(.130)\end{array}$ \\
\hline Male head & --- & --- & $\begin{array}{l}-0.339 \\
(.088)\end{array}$ & $\begin{array}{l}-0.342 \\
(.088)\end{array}$ & $\begin{array}{r}-0.331 \\
(.093)\end{array}$ & $\begin{array}{c}-0.333 \\
(.093)\end{array}$ & $\begin{array}{c}-0.314 \\
(.097)\end{array}$ & $\begin{array}{r}-0.317 \\
(.097)\end{array}$ \\
\hline Age of head & --- & $\begin{array}{l}-- \\
---\end{array}$ & --- & --- & $\begin{array}{l}-0.037 \\
(.014)\end{array}$ & $\begin{array}{r}-0.037 \\
(.014)\end{array}$ & $\begin{array}{c}-0.033 \\
(.015)\end{array}$ & $\begin{array}{c}-0.034 \\
(.015)\end{array}$ \\
\hline $\mathrm{Age}^{2}$ & --- & --- & --- & --- & $\begin{array}{l}0.0003 \\
(.0001)\end{array}$ & $\begin{array}{l}0.0003 \\
(.0001)\end{array}$ & $\begin{array}{l}0.0003 \\
(.0001)\end{array}$ & $\begin{array}{l}0.0003 \\
(.0001)\end{array}$ \\
\hline No secondary education & --- & --- & --- & --- & $\begin{array}{l}0.473 \\
(.089)\end{array}$ & $\begin{array}{l}0.464 \\
(.089)\end{array}$ & $\begin{array}{l}0.447 \\
(.093)\end{array}$ & $\begin{array}{l}0.439 \\
(.093)\end{array}$ \\
\hline Post secondary education & --- & --- & --- & --- & $\begin{array}{c}-0.333 \\
(.132)\end{array}$ & $\begin{array}{c}-0.333 \\
(.133)\end{array}$ & $\begin{array}{r}-0.351 \\
(.138)\end{array}$ & $\begin{array}{r}-0.349 \\
(.139)\end{array}$ \\
\hline North & --- & --- & --- & --- & --- & --- & $\begin{array}{l}0.217 \\
(.126)\end{array}$ & $\begin{array}{l}0.219 \\
(.127)\end{array}$ \\
\hline East & --- & --- & --- & --- & --- & --- & $\begin{array}{l}0.044 \\
(.131)\end{array}$ & $\begin{array}{l}0.053 \\
(.132)\end{array}$ \\
\hline West & --- & --- & --- & --- & --- & --- & $\begin{array}{l}0.185 \\
(.107)\end{array}$ & $\begin{array}{l}0.189 \\
(.107)\end{array}$ \\
\hline Metropolitan area & --- & --- & --- & --- & --- & --- & $\begin{array}{l}0.105 \\
(.110)\end{array}$ & $\begin{array}{l}0.103 \\
(.110)\end{array}$ \\
\hline Rural area & --- & --- & --- & $\begin{array}{l}-- \\
---\end{array}$ & --- & --- & $\begin{array}{r}-0.069 \\
(.094)\end{array}$ & $\begin{array}{r}-0.069 \\
(.094)\end{array}$ \\
\hline Renting housing unit & --- & --- & --- & --- & --- & --- & $\begin{array}{l}0.820 \\
(.168)\end{array}$ & $\begin{array}{l}0.822 \\
(.168)\end{array}$ \\
\hline $\log$ likelihood $(\mathrm{N}=6567)$ & -732 & -732 & -612 & -611 & -581 & -581 & -556 & -556 \\
\hline
\end{tabular}

Source: SOEP 1996, Authors' calculations 
Table 4: $\quad$ Social Assistance Take-up (Probit with HLU=1,0; standard error in parenthesis)

\begin{tabular}{|c|c|c|c|c|c|c|c|c|}
\hline Variable & $1 \mathrm{a}$ & $1 \mathrm{~b}$ & $2 \mathrm{a}$ & $2 b$ & $3 a$ & $3 b$ & $4 \mathrm{a}$ & $4 \mathrm{~b}$ \\
\hline Intercept & $\begin{array}{l}0.058 \\
(.171)\end{array}$ & $\begin{array}{l}0.059 \\
(.171)\end{array}$ & $\begin{array}{l}0.487 \\
(.467)\end{array}$ & $\begin{array}{l}0.467 \\
(.484)\end{array}$ & $\begin{array}{l}-0.508 \\
(.682)\end{array}$ & $\begin{array}{l}-0.518 \\
(.690)\end{array}$ & $\begin{array}{l}-0.667 \\
(.894)\end{array}$ & $\begin{array}{l}-0.621 \\
(.902)\end{array}$ \\
\hline Immigrant household & $\begin{array}{l}0.255 \\
(.145)\end{array}$ & $\begin{array}{l}0.254 \\
(.147)\end{array}$ & $\begin{array}{l}0.305 \\
(.162)\end{array}$ & $\begin{array}{l}0.311 \\
(.167)\end{array}$ & $\begin{array}{l}0.156 \\
(.171)\end{array}$ & $\begin{array}{l}0.159 \\
(.176)\end{array}$ & $\begin{array}{c}-0.116 \\
(.193)\end{array}$ & $\begin{array}{l}-0.141 \\
(.199)\end{array}$ \\
\hline $\begin{array}{l}\text { Immigrant head, native } \\
\text { spouse }\end{array}$ & --- & $\begin{array}{c}-0.176 \\
(.428)\end{array}$ & --- & $\begin{array}{l}0.069 \\
(.457)\end{array}$ & --- & $\begin{array}{l}0.048 \\
(.467)\end{array}$ & --- & $\begin{array}{l}-0.112 \\
(.466)\end{array}$ \\
\hline $\begin{array}{l}\text { Native head, immigrant } \\
\text { spouse }\end{array}$ & $\begin{array}{l}--- \\
---\end{array}$ & $\begin{array}{l}0.175 \\
(.490)\end{array}$ & $\begin{array}{l}--- \\
---\end{array}$ & $\begin{array}{l}0.042 \\
(.564)\end{array}$ & $\begin{array}{l}--- \\
---\end{array}$ & $\begin{array}{l}0.012 \\
(.570)\end{array}$ & --- & $\begin{array}{l}-0.279 \\
(.580)\end{array}$ \\
\hline Predicted Income $(* 1000)$ & $\begin{array}{l}-0.129 \\
(.058)\end{array}$ & $\begin{array}{l}-0.128 \\
(.059)\end{array}$ & $\begin{array}{l}-0.286 \\
(.122)\end{array}$ & $\begin{array}{l}-0.284 \\
(.122)\end{array}$ & $\begin{array}{l}-0.416 \\
(.160)\end{array}$ & $\begin{array}{l}-0.416 \\
(.160)\end{array}$ & $\begin{array}{r}-0.624 \\
(.224)\end{array}$ & $\begin{array}{c}-0.631 \\
(.225\end{array}$ \\
\hline Number of children $0-3$ & $\begin{array}{l}--- \\
---\end{array}$ & $\begin{array}{l}--- \\
---\end{array}$ & $\begin{array}{l}0.332 \\
(.196)\end{array}$ & $\begin{array}{l}0.334 \\
(.196)\end{array}$ & $\begin{array}{l}0.309 \\
(.208)\end{array}$ & $\begin{array}{l}0.310 \\
(.209)\end{array}$ & $\begin{array}{l}0.229 \\
(.235)\end{array}$ & $\begin{array}{l}0.221 \\
(.236)\end{array}$ \\
\hline Number of children 4-6 & --- & $\begin{array}{l}--- \\
---\end{array}$ & $\begin{array}{l}-0.123 \\
(.189)\end{array}$ & $\begin{array}{l}-0.124 \\
(.189)\end{array}$ & $\begin{array}{l}-0.087 \\
(.192)\end{array}$ & $\begin{array}{l}-0.087 \\
(.192)\end{array}$ & $\begin{array}{r}-0.159 \\
(.212)\end{array}$ & $\begin{array}{l}-0.156 \\
(.212)\end{array}$ \\
\hline Number of children $7-16$ & $\begin{array}{l}--- \\
---\end{array}$ & $\begin{array}{l}--- \\
---\end{array}$ & $\begin{array}{l}0.159 \\
(.086)\end{array}$ & $\begin{array}{l}0.160 \\
(.086)\end{array}$ & $\begin{array}{l}0.124 \\
(.090)\end{array}$ & $\begin{array}{l}0.124 \\
(.091)\end{array}$ & $\begin{array}{l}0.141 \\
(.095)\end{array}$ & $\begin{array}{l}0.139 \\
(.095)\end{array}$ \\
\hline Single-adult household & $\begin{array}{l}--- \\
---\end{array}$ & $\begin{array}{l}--- \\
---\end{array}$ & $\begin{array}{l}-1.275 \\
(.363)\end{array}$ & $\begin{array}{l}-1.264 \\
(.368)\end{array}$ & $\begin{array}{l}-1.538 \\
(.404)\end{array}$ & $\begin{array}{l}-1.534 \\
(.407)\end{array}$ & $\begin{array}{c}-1.936 \\
(.479)\end{array}$ & $\begin{array}{l}-1.964 \\
(.483)\end{array}$ \\
\hline Single adult with children & $\begin{array}{l}--- \\
---\end{array}$ & $\begin{array}{l}--- \\
---\end{array}$ & $\begin{array}{l}-0.699 \\
(.340)\end{array}$ & $\begin{array}{l}-0.692 \\
(.343)\end{array}$ & $\begin{array}{l}-0.811 \\
(.356)\end{array}$ & $\begin{array}{c}-0.808 \\
(.359)\end{array}$ & $\begin{array}{l}-1.004 \\
(.382)\end{array}$ & $\begin{array}{l}-1.026 \\
(.385)\end{array}$ \\
\hline $\begin{array}{l}\text { Several adults with } \\
\text { children }\end{array}$ & $\begin{array}{l}--- \\
---\end{array}$ & $\begin{array}{l}--- \\
---\end{array}$ & $\begin{array}{l}-0.102 \\
(.295)\end{array}$ & $\begin{array}{l}-0.098 \\
(.297)\end{array}$ & $\begin{array}{l}0.008 \\
(.319)\end{array}$ & $\begin{array}{l}0.012 \\
(.322)\end{array}$ & $\begin{array}{l}0.228 \\
(.381)\end{array}$ & $\begin{array}{l}0.229 \\
(.383)\end{array}$ \\
\hline Not married & $\begin{array}{l}--- \\
---\end{array}$ & $\begin{array}{l}--- \\
---\end{array}$ & $\begin{array}{l}0.740 \\
(.223)\end{array}$ & $\begin{array}{l}0.747 \\
(.227)\end{array}$ & $\begin{array}{l}0.894 \\
(.236)\end{array}$ & $\begin{array}{l}0.898 \\
(.240)\end{array}$ & $\begin{array}{l}1.046 \\
(.257)\end{array}$ & $\begin{array}{l}1.034 \\
(.260)\end{array}$ \\
\hline Male head & $\begin{array}{l}--- \\
---\end{array}$ & $\begin{array}{l}--- \\
---\end{array}$ & $\begin{array}{l}-0.237 \\
(.169)\end{array}$ & $\begin{array}{l}-0.238 \\
(.169)\end{array}$ & $\begin{array}{l}-0.149 \\
(.179)\end{array}$ & $\begin{array}{l}-0.150 \\
(.179)\end{array}$ & $\begin{array}{l}-0.026 \\
(.192)\end{array}$ & $\begin{array}{l}-0.028 \\
(.192)\end{array}$ \\
\hline Age of head & $\begin{array}{l}--- \\
---\end{array}$ & $\begin{array}{l}--- \\
---\end{array}$ & $\begin{array}{l}--- \\
---\end{array}$ & $\begin{array}{l}--- \\
---\end{array}$ & $\begin{array}{l}0.051 \\
(.028)\end{array}$ & $\begin{array}{l}0.051 \\
(.028)\end{array}$ & $\begin{array}{l}0.070 \\
(.031)\end{array}$ & $\begin{array}{l}0.071 \\
(.031)\end{array}$ \\
\hline $\mathrm{Age}^{2}$ & --- & --- & --- & --- & $\begin{array}{l}-0.0005 \\
(.0003)\end{array}$ & $\begin{array}{c}-0.0005 \\
(.0003)\end{array}$ & $\begin{array}{c}-0.0006 \\
(.0003)\end{array}$ & $\begin{array}{l}-0.0006 \\
(.0003)\end{array}$ \\
\hline No secondary education & $\begin{array}{l}--- \\
---\end{array}$ & $\begin{array}{l}--- \\
---\end{array}$ & $\begin{array}{l}--- \\
---\end{array}$ & $\begin{array}{l}--- \\
---\end{array}$ & $\begin{array}{l}0.275 \\
(.161)\end{array}$ & $\begin{array}{l}0.274 \\
(.162)\end{array}$ & $\begin{array}{l}0.107 \\
(.185)\end{array}$ & $\begin{array}{l}0.112 \\
(.186)\end{array}$ \\
\hline Post secondary education & $\begin{array}{l}--- \\
---\end{array}$ & $\begin{array}{l}--- \\
---\end{array}$ & --- & $\begin{array}{l}--- \\
---\end{array}$ & $\begin{array}{l}0.360 \\
(.300)\end{array}$ & $\begin{array}{l}0.360 \\
(.300)\end{array}$ & $\begin{array}{l}0.397 \\
(.334)\end{array}$ & $\begin{array}{r}-0.397 \\
(.334)\end{array}$ \\
\hline North & --- & --- & --- & --- & $\begin{array}{l}--- \\
---\end{array}$ & --- & $\begin{array}{l}0.205 \\
(.235)\end{array}$ & $\begin{array}{l}0.204 \\
(.236)\end{array}$ \\
\hline East & --- & --- & --- & --- & --- & $\begin{array}{l}--- \\
---\end{array}$ & $\begin{array}{c}-0.452 \\
(.280)\end{array}$ & $\begin{array}{r}-0.459 \\
(.280)\end{array}$ \\
\hline West & --- & --- & --- & --- & --- & --- & $\begin{array}{l}0.209 \\
(.195)\end{array}$ & $\begin{array}{l}0.212 \\
(.195)\end{array}$ \\
\hline Metropolitan area & --- & --- & --- & $\begin{array}{l}--- \\
---\end{array}$ & $\begin{array}{l}--- \\
---\end{array}$ & $\begin{array}{l}--- \\
---\end{array}$ & $\begin{array}{l}0.378 \\
(.213)\end{array}$ & $\begin{array}{l}0.378 \\
(.214)\end{array}$ \\
\hline Rural area & --- & $\begin{array}{l}--- \\
---\end{array}$ & --- & --- & --- & $\begin{array}{l}--- \\
---\end{array}$ & $\begin{array}{r}-0.181 \\
(.177)\end{array}$ & $\begin{array}{r}-0.192 \\
(.179)\end{array}$ \\
\hline Renting housing unit & --- & --- & --- & --- & --- & $\begin{array}{l}--- \\
---\end{array}$ & $\begin{array}{l}0.319 \\
(.337)\end{array}$ & $\begin{array}{l}0.318 \\
(.337)\end{array}$ \\
\hline $\log$ likelihood $(\mathrm{N}=365)$ & -244 & -244 & \begin{tabular}{l|l|}
-222 \\
\end{tabular} & -222 & -218 & -218 & -207 & -207 \\
\hline
\end{tabular}

Source: SOEP 1996, Authors' calculations 
Table 5: $\quad$ Percent of households who do not take up welfare benefits:

\begin{tabular}{|l|c|}
\hline Situation & Predicted Probability of Non-take-up \\
\hline $\begin{array}{l}\text { Immigrant household, } \\
\text { all else average }\end{array}$ & $37.4 \%$ \\
Native household, all else average & $41.9 \%$ \\
\hline Average income, all else average & $40.5 \%$ \\
Average income +100, & $38.1 \%$ \\
all else average & \\
\hline
\end{tabular}

Figures in the table represent fitted values from the probit regression in column $4 \mathrm{a}$ of table 4. Source: SOEP 1996, Authors' calculations 
Table 6: $\quad$ Social Assistance Take-up with other explanatory variables (Probit with $\mathrm{HLU}=0,1$; standard errors in parenthesis)

\begin{tabular}{|c|c|c|c|c|c|c|}
\hline \multirow[t]{2}{*}{ Variable } & \multicolumn{2}{|c|}{$\begin{array}{l}\text { Immigrant Wealth } \\
\text { Interaction Terms }\end{array}$} & \multicolumn{2}{|c|}{$\begin{array}{l}\text { States (not Regions) and } \\
\text { Subjective Measures }\end{array}$} & \multicolumn{2}{|c|}{$\begin{array}{l}\text { Integration Measures } \\
\text { (for Immigrants only) }\end{array}$} \\
\hline & $\beta$ & Std. Err. & $\beta$ & Std. Err. & $\beta$ & Std. Err. \\
\hline Intercept & -0.648 & $(0.805)$ & -0.307 & $(0.940)$ & -0.909 & $(0.910)$ \\
\hline Immigrant household & --- & --- & -0.176 & $(0.203)$ & -0.411 & $(0.238)$ \\
\hline Immigrant without other wealth & 0.131 & $(0.294)$ & --- & --- & --- & --- \\
\hline Immigrant with other wealth & -6.904 & $(8011)$ & --- & --- & --- & --- \\
\hline Native without other wealth & 0.231 & $(0.265)$ & --- & --- & --- & --- \\
\hline Predicted Income $(* 1000)$ & -0.596 & $(0.211)$ & -0.619 & $(0.235)$ & -0.606 & $(0.226)$ \\
\hline Single-adult household & -1.918 & $(0.461)$ & -1.886 & $(0.502)$ & -1.867 & $(0.484)$ \\
\hline Single adult with children & -1.068 & $(0.377)$ & -0.850 & $(0.398)$ & -0.949 & $(0.386)$ \\
\hline Several adults with children & 0.137 & $(0.382)$ & 0.345 & $(0.397)$ & 0.239 & $(0.386)$ \\
\hline Not married & 1.061 & $(0.261)$ & 0.943 & $(0.269)$ & 1.049 & $(0.260)$ \\
\hline Male head & -0.005 & $(0.192)$ & -0.071 & $(0.202)$ & -0.017 & $(0.194)$ \\
\hline Age of head & 0.070 & $(0.030)$ & 0.059 & $(0.033)$ & 0.076 & $(0.031)$ \\
\hline $\mathrm{Age}^{2}$ & -0.0006 & $(.0003)$ & -0.0005 & $(0.0003)$ & -0.0007 & $(0.0003$ \\
\hline North & 0.225 & $(0.236)$ & --- & --- & 0.231 & $(0.239)$ \\
\hline East & -0.448 & $(0.277)$ & --- & --- & -0.395 & $(0.283)$ \\
\hline West & 0.215 & $(0.196)$ & --- & --- & 0.198 & $(0.200)$ \\
\hline Metropolitan area & 0.367 & $(0.213)$ & 0.707 & $(0.265)$ & 0.378 & $(0.217)$ \\
\hline Rural area & -0.206 & $(0.170)$ & -0.309 & $(0.196)$ & -0.186 & $(0.180)$ \\
\hline Renting housing unit & --- & --- & 0.302 & $(0.348)$ & 0.298 & $(0.340)$ \\
\hline Head worries deeply about the economy & --- & --- & 0.020 & $(0.163)$ & --- & --- \\
\hline Worries about the situation of Foreigners & --- & --- & -0.056 & $(0.159)$ & --- & --- \\
\hline Head's satisfaction with life (scale $0-10$ ) & --- & --- & -0.061 & $(0.170)$ & --- & --- \\
\hline Berlin (West) & --- & --- & -0.646 & $(0.427)$ & --- & --- \\
\hline Schleswig-Holstein & --- & --- & 0.286 & $(0.541)$ & --- & --- \\
\hline Hamburg or Bremen & --- & --- & -0.239 & $(0.568)$ & --- & --- \\
\hline Lower Saxony & --- & --- & 0.466 & $(0.300)$ & --- & --- \\
\hline Hesse & --- & --- & 0.407 & $(0.344)$ & --- & --- \\
\hline Rhineland-Palatinate or Saarland & --- & --- & 0.407 & $(0.349)$ & --- & --- \\
\hline Baden-Wurttemberg & --- & --- & -0.002 & $(0.263)$ & --- & --- \\
\hline Bavaria & --- & --- & -0.062 & $(0.290)$ & --- & --- \\
\hline Mecklenburg-West Pomerania & --- & --- & 0.583 & $(0.536)$ & --- & --- \\
\hline Brandenburg & --- & --- & -0.678 & $(0.431)$ & --- & --- \\
\hline Saxony-Anhalt & --- & --- & -0.703 & $(0.490)$ & --- & --- \\
\hline Thuringia & --- & --- & -0.280 & $(0.424)$ & --- & --- \\
\hline Saxony & --- & --- & -0.981 & $(0.431)$ & --- & --- \\
\hline Language at home is mainly German & --- & --- & --- & --- & -0.016 & $(0.275)$ \\
\hline Wants to stay in Germany & --- & --- & --- & --- & 0.526 & $(0.252)$ \\
\hline Would apply for Dual Citizenship & --- & --- & --- & --- & 0.186 & $(0.279)$ \\
\hline Never feels rootless & --- & --- & --- & --- & 0.068 & $(0.274)$ \\
\hline Has not felt disadvantage because foreign & --- & --- & --- & --- & -0.183 & $(0.250)$ \\
\hline $\log$ likelihood $(n=365)$ & -205.17 & & -199.65 & & -204.22 & \\
\hline
\end{tabular}

The regressions also include variables for number of children, and education.

Source: SOEP 1996, Authors' calculations. 
Table 7: $\quad$ Social Assistance Take-up with immigrant cohort and country of origin (Probit with HLU= 0,1; standard errors in parenthesis)

\begin{tabular}{|c|c|c|c|c|}
\hline & \multicolumn{2}{|c|}{$\begin{array}{c}\text { Country of Origin } \\
\text { Instead of Immigrant Status }\end{array}$} & \multicolumn{2}{|c|}{$\begin{array}{l}\text { Immigration Cohort } \\
\text { Instead of Immigrant Status }\end{array}$} \\
\hline & $\beta$ & Std. Err. & $\beta$ & Std. Err. \\
\hline Intercept & -0.735 & $(.913)$ & -0.726 & $(0.907)$ \\
\hline Predicted Income $(* 1000)$ & -0.609 & $(0.225)$ & -0.630 & $(0.224)$ \\
\hline From USA, C, NZ, Australia & -0.154 & $(0.970)$ & --- & --- \\
\hline From former USSR and East & -0.030 & $(0.254)$ & --- & --- \\
\hline From European Union country & -0.558 & $(0.342)$ & --- & --- \\
\hline From Turkey, Ex-Yugoslavia & -0.173 & $(0.241)$ & --- & --- \\
\hline From other country & 0.710 & $(0.690)$ & --- & --- \\
\hline Immigrated 1948-1965 & --- & --- & -0.071 & $(0.457)$ \\
\hline Immigrated 1966-1975 & --- & --- & -0.063 & $(0.263)$ \\
\hline Immigrated 1976-1985 & --- & --- & -0.547 & $(0.386)$ \\
\hline Immigrated 1986-1990 & --- & --- & -0.427 & $(0.292)$ \\
\hline Immigrated 1991-1996 & --- & --- & 0.192 & $(0.300)$ \\
\hline Number of children $0-3$ & 0.232 & $(0.237)$ & 0.210 & $(0.237)$ \\
\hline Number of children 4-6 & -0.159 & $(0.213)$ & -0.097 & $(0.216)$ \\
\hline Number of children 7-16 & 0.132 & $(0.096)$ & 0.247 & $(0.098)$ \\
\hline Single-adult household & -1.924 & $(0.487)$ & -1.917 & $(0.483)$ \\
\hline Single adult with children & -0.996 & $(0.388)$ & -0.949 & $(0.386)$ \\
\hline Several adults with children & 0.256 & $(0.379)$ & 0.236 & $(0.382)$ \\
\hline Not married & 1.050 & $(0.262)$ & 1.063 & $(0.259)$ \\
\hline Male head & -0.007 & $(0.194)$ & 0.006 & $(0.193)$ \\
\hline Age of head & 0.071 & $(0.031)$ & 0.073 & $(0.031)$ \\
\hline $\operatorname{Age}^{2}$ & -0.0006 & $(.0003)$ & -0.0006 & $(.0003)$ \\
\hline No secondary education & 0.150 & $(0.188)$ & 0.103 & $(0.187)$ \\
\hline Post secondary education & 0.347 & $(0.334)$ & 0.399 & $(0.334)$ \\
\hline North & 0.173 & $(0.238)$ & 0.195 & $(0.238)$ \\
\hline East & -0.461 & $(0.278)$ & -0.473 & $(0.278)$ \\
\hline West & 0.200 & $(0.198)$ & 0.225 & $(0.196)$ \\
\hline Metropolitan area & 0.347 & $(0.217)$ & 0.388 & $(0.216)$ \\
\hline Rural area & -0.209 & $(0.180)$ & -0.205 & $(0.179)$ \\
\hline Renting housing unit & 0.330 & $(0.338)$ & 0.304 & $(0.340)$ \\
\hline log likelihood $(\mathrm{n}=365)$ & \multicolumn{2}{|c|}{-205.30} & \multicolumn{2}{|c|}{-205.04} \\
\hline
\end{tabular}

Source: SOEP 1996, Authors' calculations 
Appendix: Table A1: OLS regression of Income (Instrument for Tables 4ff.)

\begin{tabular}{|c|c|c|c|}
\hline \multicolumn{2}{|l|}{ Variable } & $B$ & Std. Err. \\
\hline \multicolumn{2}{|l|}{ Intercept } & 1893.3 & $(251.1)$ \\
\hline \multicolumn{2}{|c|}{ Immigrant household } & -205.0 & $(77.1)$ \\
\hline \multicolumn{2}{|c|}{ Number of children age $0-3$} & -527.9 & $(75.7)$ \\
\hline \multicolumn{2}{|c|}{ Number of children age 4-7 } & -264.9 & $(71.3)$ \\
\hline \multicolumn{2}{|c|}{ Number of children age 7-16 } & -76.1 & $(37.7)$ \\
\hline \multicolumn{2}{|c|}{ Single adult household } & -1657.6 & $(86.6)$ \\
\hline \multicolumn{2}{|c|}{ Single adult with children } & -719.8 & $(122.8)$ \\
\hline \multicolumn{2}{|c|}{ Several adults with children } & 957.9 & $(69.8)$ \\
\hline \multicolumn{2}{|c|}{ Not married } & 359.5 & $(78.5)$ \\
\hline \multicolumn{2}{|c|}{ Male Head } & 311.2 & $(58.1)$ \\
\hline \multicolumn{2}{|c|}{ Age of Head } & 73.4 & $(9.5)$ \\
\hline \multicolumn{2}{|l|}{$\mathrm{Age}^{2}$} & -0.6 & $(0.09)$ \\
\hline \multicolumn{2}{|c|}{ No secondary education } & 285.5 & (64.9) \\
\hline \multicolumn{2}{|c|}{ Post secondary education } & 529.3 & $(60.0)$ \\
\hline \multicolumn{2}{|c|}{ Living in North } & -109.8 & $(74.2)$ \\
\hline \multicolumn{2}{|c|}{ Living in East } & -770.0 & (66.9) \\
\hline \multicolumn{2}{|c|}{ Living in West } & -167.1 & $(60.8)$ \\
\hline \multicolumn{2}{|c|}{ Living in metropolitan area } & 150.5 & (69.9) \\
\hline \multicolumn{2}{|c|}{ Living in rural area } & -154.5 & $(51.2)$ \\
\hline \multicolumn{2}{|c|}{ Renting housing unit } & -673.9 & $(53.6)$ \\
\hline \multicolumn{2}{|c|}{ Father without secondary education } & -172.5 & $(60.6)$ \\
\hline \multicolumn{2}{|c|}{ Father with post secondary education } & 118.0 & $(64.1)$ \\
\hline Mother wi & thout secondary education & -146.3 & $(54.1)$ \\
\hline Mother wi & th post secondary education & 69.5 & $(113.3)$ \\
\hline ISCO: & Science & 1099.1 & (121.0) \\
\hline & Management & 1963.9 & $(168.6)$ \\
\hline & Office & 611.3 & (118.7) \\
\hline & Trade & 856.9 & $(165.6)$ \\
\hline & Service & 201.2 & (141.5) \\
\hline & Agriculture & 102.9 & $(322.3)$ \\
\hline & Manufacturing & 201.5 & $(106.5)$ \\
\hline Industry: & Agriculture & -172.7 & $(322.5)$ \\
\hline & Energy & 244.6 & $(210.5)$ \\
\hline & Chemistry & 645.7 & (161.4) \\
\hline & Plastics & 462.3 & $(318.9)$ \\
\hline & Stone & -2.2 & $(353.7)$ \\
\hline & Metal & 490.7 & (110.4) \\
\hline & Wood & 462.6 & (194.4) \\
\hline & Textile & 232.3 & $(275.2)$ \\
\hline & Food & -206.3 & (205.8) \\
\hline & Construction & 314.5 & (123.4) \\
\hline & Trade & 49.8 & (141.1) \\
\hline & Transportation & 82.1 & $(140.3)$ \\
\hline & Banking & 485.9 & (176.7) \\
\hline & Other service & 174.8 & $(119.0)$ \\
\hline & Non-profit & -158.0 & $(212.9)$ \\
\hline & Public Sector & 244.4 & (127.9) \\
\hline Adj. R-Squ & uared $(\mathrm{N}=6567)$ & & \\
\hline
\end{tabular}

Source: SOEP 1996, Authors' calculations 
Table A2: Social Assistance Take-up (Logistic; with HLU=1,0; std. Err. in parenthesis; $\mathrm{n}=365)$

\begin{tabular}{|c|c|c|c|c|c|c|c|c|}
\hline Variable & $1 \mathrm{a}$ & $1 \mathrm{~b}$ & $2 \mathrm{a}$ & $2 b$ & $3 a$ & $3 b$ & $4 a$ & $4 \mathrm{~b}$ \\
\hline Intercept & $\begin{array}{l}0.089 \\
(.274)\end{array}$ & $\begin{array}{l}0.090 \\
(.274)\end{array}$ & $\begin{array}{l}0.785 \\
(.765)\end{array}$ & $\begin{array}{l}0.753 \\
(.789)\end{array}$ & $\begin{array}{l}-0.831 \\
(1.126)\end{array}$ & $\begin{array}{l}-0.852 \\
(1.140)\end{array}$ & $\begin{array}{l}-1.183 \\
(1.531)\end{array}$ & $\begin{array}{l}-1.089 \\
(1.542)\end{array}$ \\
\hline Immigrant household & $\begin{array}{l}0.408 \\
(.233)\end{array}$ & $\begin{array}{l}0.405 \\
(.237)\end{array}$ & $\begin{array}{l}0.493 \\
(.266)\end{array}$ & $\begin{array}{l}0.504 \\
(.274)\end{array}$ & $\begin{array}{l}0.254 \\
(.281)\end{array}$ & $\begin{array}{l}0.260 \\
(.289)\end{array}$ & $\begin{array}{l}-0.193 \\
(.317)\end{array}$ & $\begin{array}{l}-0.249 \\
(.331)\end{array}$ \\
\hline $\begin{array}{l}\text { Immigrant head, native } \\
\text { spouse }\end{array}$ & $\begin{array}{l}--- \\
---\end{array}$ & $\begin{array}{l}-0.287 \\
(.707)\end{array}$ & $\begin{array}{l}--- \\
---\end{array}$ & $\begin{array}{l}0.107 \\
(.752)\end{array}$ & $\begin{array}{l}--- \\
---\end{array}$ & $\begin{array}{l}0.098 \\
(.765)\end{array}$ & $\begin{array}{l}--- \\
---\end{array}$ & $\begin{array}{c}-0.320 \\
(.801)\end{array}$ \\
\hline $\begin{array}{l}\text { Native head, immigrant } \\
\text { spouse }\end{array}$ & --- & $\begin{array}{l}0.284 \\
(.780)\end{array}$ & $\begin{array}{l}--- \\
---\end{array}$ & $\begin{array}{l}0.086 \\
(.891)\end{array}$ & $\begin{array}{l}--- \\
---\end{array}$ & $\begin{array}{l}-0.006 \\
(.902)\end{array}$ & --- & $\begin{array}{l}-0.479 \\
(.939)\end{array}$ \\
\hline Predicted Income $(* 1000)$ & $\begin{array}{l}-0.204 \\
(.094)\end{array}$ & $\begin{array}{l}-0.203 \\
(.095)\end{array}$ & $\begin{array}{l}-0.456 \\
(.201)\end{array}$ & $\begin{array}{l}-0.453 \\
(.202)\end{array}$ & $\begin{array}{l}-0.676 \\
(.268)\end{array}$ & $\begin{array}{c}-0.676 \\
(.268)\end{array}$ & $\begin{array}{r}-1.050 \\
(.382)\end{array}$ & $\begin{array}{l}-1.064 \\
(.383)\end{array}$ \\
\hline Number of children $0-3$ & $\begin{array}{l}--- \\
---\end{array}$ & $\begin{array}{l}--- \\
---\end{array}$ & $\begin{array}{l}0.538 \\
(.324)\end{array}$ & $\begin{array}{l}0.542 \\
(.325)\end{array}$ & $\begin{array}{l}0.495 \\
(.346)\end{array}$ & $\begin{array}{l}0.497 \\
(.347)\end{array}$ & $\begin{array}{l}0.360 \\
(.393)\end{array}$ & $\begin{array}{l}0.343 \\
(.395)\end{array}$ \\
\hline Number of children 4-6 & --- & --- & $\begin{array}{l}-0.186 \\
(.310)\end{array}$ & $\begin{array}{l}-0.187 \\
(.310)\end{array}$ & $\begin{array}{l}-0.131 \\
(.316)\end{array}$ & $\begin{array}{l}-0.131 \\
(.316)\end{array}$ & $\begin{array}{l}-0.236 \\
(.352)\end{array}$ & $\begin{array}{l}-0.229 \\
(.352)\end{array}$ \\
\hline Number of children $7-16$ & $\begin{array}{l}--- \\
---\end{array}$ & $\begin{array}{l}--- \\
---\end{array}$ & $\begin{array}{l}0.263 \\
(.143)\end{array}$ & $\begin{array}{l}0.265 \\
(.144)\end{array}$ & $\begin{array}{l}0.207 \\
(.149)\end{array}$ & $\begin{array}{l}0.208 \\
(.149)\end{array}$ & $\begin{array}{l}0.229 \\
(.157)\end{array}$ & $\begin{array}{l}0.224 \\
(.157)\end{array}$ \\
\hline Single-adult household & $\begin{array}{l}--- \\
---\end{array}$ & $\begin{array}{l}--- \\
---\end{array}$ & $\begin{array}{l}-2.070 \\
(.603)\end{array}$ & $\begin{array}{l}-2.055 \\
(.609)\end{array}$ & $\begin{array}{l}-2.512 \\
(.676)\end{array}$ & $\begin{array}{l}-2.505 \\
(.680)\end{array}$ & $\begin{array}{r}-3.260 \\
(.828)\end{array}$ & $\begin{array}{l}-3.316 \\
(.835)\end{array}$ \\
\hline Single adult with children & $\begin{array}{l}--- \\
---\end{array}$ & $\begin{array}{l}--- \\
---\end{array}$ & $\begin{array}{r}-1.143 \\
(.560)\end{array}$ & $\begin{array}{l}-1.133 \\
(.563)\end{array}$ & $\begin{array}{l}-1.336 \\
(.589)\end{array}$ & $\begin{array}{l}-1.331 \\
(.593)\end{array}$ & $\begin{array}{r}-1.710 \\
(.651)\end{array}$ & $\begin{array}{l}-1.751 \\
(.656)\end{array}$ \\
\hline $\begin{array}{l}\text { Several adults with } \\
\text { children }\end{array}$ & $\begin{array}{l}--- \\
---\end{array}$ & $\begin{array}{l}--- \\
---\end{array}$ & $\begin{array}{l}-0.185 \\
(.489)\end{array}$ & $\begin{array}{l}-0.182 \\
(.491)\end{array}$ & $\begin{array}{l}0.005 \\
(.528)\end{array}$ & $\begin{array}{l}0.002 \\
(.531)\end{array}$ & $\begin{array}{l}0.399 \\
(.642)\end{array}$ & $\begin{array}{l}0.402 \\
(.643)\end{array}$ \\
\hline Not married & --- & --- & $\begin{array}{l}1.190 \\
(.366)\end{array}$ & $\begin{array}{l}1.200 \\
(.373)\end{array}$ & $\begin{array}{l}1.446 \\
(.391)\end{array}$ & $\begin{array}{l}1.455 \\
(.397)\end{array}$ & $\begin{array}{l}1.745 \\
(.433)\end{array}$ & $\begin{array}{l}1.713 \\
(.437)\end{array}$ \\
\hline Male head & $\begin{array}{l}--- \\
---\end{array}$ & $\begin{array}{l}--- \\
---\end{array}$ & $\begin{array}{l}-0.392 \\
(.279)\end{array}$ & $\begin{array}{l}-0.392 \\
(.278)\end{array}$ & $\begin{array}{l}-0.246 \\
(.296)\end{array}$ & $\begin{array}{l}-0.248 \\
(.297)\end{array}$ & $\begin{array}{l}-0.063 \\
(.325)\end{array}$ & $\begin{array}{l}-0.064 \\
(.326)\end{array}$ \\
\hline Age of head & $\begin{array}{l}--- \\
---\end{array}$ & $\begin{array}{l}--- \\
---\end{array}$ & $\begin{array}{l}--- \\
---\end{array}$ & $\begin{array}{l}--- \\
---\end{array}$ & $\begin{array}{l}0.083 \\
(.047)\end{array}$ & $\begin{array}{l}0.083 \\
(.047)\end{array}$ & $\begin{array}{l}0.122 \\
(.052)\end{array}$ & $\begin{array}{l}0.123 \\
(.052)\end{array}$ \\
\hline $\mathrm{Age}^{2}$ & $\begin{array}{l}--- \\
---\end{array}$ & $\begin{array}{l}--- \\
---\end{array}$ & $\begin{array}{l}-- \\
---\end{array}$ & $\begin{array}{l}--- \\
---\end{array}$ & $\begin{array}{c}-0.0008 \\
(.0005)\end{array}$ & $\begin{array}{c}-0.0008 \\
(.0005)\end{array}$ & $\begin{array}{c}-0.0011 \\
(.0005)\end{array}$ & $\begin{array}{c}-0.0011 \\
(.0005)\end{array}$ \\
\hline No secondary education & $\begin{array}{l}--- \\
---\end{array}$ & $\begin{array}{l}--- \\
---\end{array}$ & $\begin{array}{l}--- \\
---\end{array}$ & $\begin{array}{l}--- \\
---\end{array}$ & $\begin{array}{l}0.458 \\
(.267)\end{array}$ & $\begin{array}{l}0.456 \\
(.269)\end{array}$ & $\begin{array}{l}0.161 \\
(.311)\end{array}$ & $\begin{array}{l}0.173 \\
(.311)\end{array}$ \\
\hline Post secondary education & --- & --- & --- & --- & $\begin{array}{l}0.622 \\
(.499)\end{array}$ & $\begin{array}{l}0.623 \\
(.499)\end{array}$ & $\begin{array}{l}0.717 \\
(.557)\end{array}$ & $\begin{array}{l}0.717 \\
(.557)\end{array}$ \\
\hline North & --- & --- & --- & --- & --- & --- & $\begin{array}{l}0.312 \\
(.392)\end{array}$ & $\begin{array}{l}0.316 \\
(.394)\end{array}$ \\
\hline East & $\begin{array}{l}--- \\
---\end{array}$ & $\begin{array}{l}--- \\
---\end{array}$ & $\begin{array}{l}--- \\
---\end{array}$ & $\begin{array}{l}--- \\
---\end{array}$ & $\begin{array}{l}--- \\
---\end{array}$ & $\begin{array}{l}--- \\
---\end{array}$ & $\begin{array}{c}-0.831 \\
(.482)\end{array}$ & $\begin{array}{l}-0.849 \\
(.483)\end{array}$ \\
\hline West & $\begin{array}{l}--- \\
---\end{array}$ & $\begin{array}{l}--- \\
---\end{array}$ & --- & $\begin{array}{l}--- \\
---\end{array}$ & $\begin{array}{l}--- \\
---\end{array}$ & $\begin{array}{l}--- \\
---\end{array}$ & $\begin{array}{l}0.349 \\
(.322)\end{array}$ & $\begin{array}{l}0.354 \\
(.322)\end{array}$ \\
\hline Metropolitan area & $\begin{array}{l}--- \\
---\end{array}$ & --- & --- & $\begin{array}{l}--- \\
---\end{array}$ & $\begin{array}{l}--- \\
---\end{array}$ & $\begin{array}{l}--- \\
---\end{array}$ & $\begin{array}{l}0.626 \\
(.352)\end{array}$ & $\begin{array}{l}0.626 \\
(.352)\end{array}$ \\
\hline Rural area & --- & --- & $\begin{array}{l}--- \\
---\end{array}$ & $\begin{array}{l}--- \\
---\end{array}$ & --- & $\begin{array}{l}--- \\
---\end{array}$ & $\begin{array}{c}-0.293 \\
(.293)\end{array}$ & $\begin{array}{c}-0.315 \\
(.295)\end{array}$ \\
\hline Renting housing unit & --- & --- & --- & --- & --- & $\begin{array}{l}--- \\
---\end{array}$ & $\begin{array}{l}0.572 \\
(.594)\end{array}$ & $\begin{array}{l}0.583 \\
(.595)\end{array}$ \\
\hline
\end{tabular}

Source: SOEP 1996, Authors' calculations 
Table A3: Social Assistance Take-Up (OLS with dep. variable HLU; std. err. in parenthesis)

\begin{tabular}{|c|c|c|c|c|c|c|c|c|}
\hline Variable & $1 \mathrm{a}$ & $1 \mathrm{~b}$ & $2 \mathrm{a}$ & $2 b$ & $3 \mathrm{a}$ & $3 b$ & $4 \mathrm{a}$ & $4 \mathrm{~b}$ \\
\hline Intercept & $\begin{array}{c}0.518 \\
(0.066)\end{array}$ & $\begin{array}{c}0.519 \\
(0.066)\end{array}$ & $\begin{array}{c}0.641 \\
(0.162)\end{array}$ & $\begin{array}{c}0.635 \\
(0.168)\end{array}$ & $\begin{array}{c}0.301 \\
(0.234)\end{array}$ & $\begin{array}{c}0.299 \\
(0.238)\end{array}$ & $\begin{array}{l}0.270 \\
(0.293)\end{array}$ & $\begin{array}{c}0.292 \\
(0.296)\end{array}$ \\
\hline Immigrant household & $\begin{array}{c}0.098 \\
(0.056)\end{array}$ & $\begin{array}{c}0.097 \\
(0.057)\end{array}$ & $\begin{array}{c}0.106 \\
(0.057)\end{array}$ & $\begin{array}{c}0.108 \\
(0.059)\end{array}$ & $\begin{array}{c}0.055 \\
(0.060)\end{array}$ & $\begin{array}{c}0.056 \\
(0.062)\end{array}$ & $\begin{array}{l}-0.032 \\
(0.065)\end{array}$ & $\begin{array}{l}-0.043 \\
(0.067)\end{array}$ \\
\hline $\begin{array}{l}\text { Immigrant head, native } \\
\text { spouse }\end{array}$ & $\begin{array}{l}--- \\
---\end{array}$ & $\begin{array}{l}-0.065 \\
(0.159)\end{array}$ & $\begin{array}{l}--- \\
---\end{array}$ & $\begin{array}{c}0.012 \\
(0.159)\end{array}$ & $\begin{array}{l}--- \\
---\end{array}$ & $\begin{array}{c}0.007 \\
(0.160)\end{array}$ & $\begin{array}{l}--- \\
---\end{array}$ & $\begin{array}{l}-0.070 \\
(0.158)\end{array}$ \\
\hline $\begin{array}{l}\text { Native head, immigrant } \\
\text { spouse }\end{array}$ & $\begin{array}{l}--- \\
---\end{array}$ & $\begin{array}{c}0.066 \\
(0.189)\end{array}$ & $\begin{array}{l}--- \\
---\end{array}$ & $\begin{array}{c}0.021 \\
(0.183)\end{array}$ & $\begin{array}{l}--- \\
---\end{array}$ & $\begin{array}{c}0.008 \\
(0.183)\end{array}$ & $\begin{array}{l}--- \\
---\end{array}$ & $\begin{array}{l}-0.089 \\
(0.182)\end{array}$ \\
\hline Predicted Income $(* 1000)$ & $\begin{array}{l}-0.048 \\
(0.022)\end{array}$ & $\begin{array}{l}-0.048 \\
(0.022)\end{array}$ & $\begin{array}{l}-0.091 \\
(0.041)\end{array}$ & $\begin{array}{l}-0.091 \\
(0.041)\end{array}$ & $\begin{array}{l}-0.124 \\
(0.051)\end{array}$ & $\begin{array}{l}-0.124 \\
(0.052)\end{array}$ & $\begin{array}{l}-0.178 \\
(0.068)\end{array}$ & $\begin{array}{l}-0.181 \\
(0.069)\end{array}$ \\
\hline Number of children $0-3$ & $\begin{array}{l}--- \\
---\end{array}$ & --- & $\begin{array}{c}0.123 \\
(0.068)\end{array}$ & $\begin{array}{c}0.124 \\
(0.068)\end{array}$ & $\begin{array}{c}0.116 \\
(0.070)\end{array}$ & $\begin{array}{c}0.116 \\
(0.071)\end{array}$ & $\begin{array}{c}0.089 \\
(0.075)\end{array}$ & $\begin{array}{c}0.086 \\
(0.075)\end{array}$ \\
\hline Number of children 4-6 & $\begin{array}{l}--- \\
---\end{array}$ & $\begin{array}{l}--- \\
---\end{array}$ & $\begin{array}{l}-0.040 \\
(0.066)\end{array}$ & $\begin{array}{l}-0.040 \\
(0.066)\end{array}$ & $\begin{array}{l}-0.028 \\
(0.066)\end{array}$ & $\begin{array}{l}-0.028 \\
(0.066)\end{array}$ & $\begin{array}{c}0.047 \\
(0.068)\end{array}$ & $\begin{array}{c}0.046 \\
(0.068)\end{array}$ \\
\hline Number of children $7-16$ & $\begin{array}{l}--- \\
---\end{array}$ & --- & $\begin{array}{c}0.058 \\
(0.030)\end{array}$ & $\begin{array}{c}0.058 \\
(0.031)\end{array}$ & $\begin{array}{c}0.046 \\
(0.031)\end{array}$ & $\begin{array}{c}0.046 \\
(0.032)\end{array}$ & $\begin{array}{c}0.051 \\
(0.032)\end{array}$ & $\begin{array}{c}0.050 \\
(0.032)\end{array}$ \\
\hline Single-adult household & $\begin{array}{l}--- \\
---\end{array}$ & --- & $\begin{array}{l}-0.447 \\
(0.125)\end{array}$ & $\begin{array}{l}-0.444 \\
(0.128)\end{array}$ & $\begin{array}{l}-0.509 \\
(0.134)\end{array}$ & $\begin{array}{l}-0.508 \\
(0.136)\end{array}$ & $\begin{array}{l}-0.605 \\
(0.151)\end{array}$ & $\begin{array}{l}-0.618 \\
(0.153)\end{array}$ \\
\hline Single adult with children & $\begin{array}{l}--- \\
---\end{array}$ & $\begin{array}{l}--- \\
---\end{array}$ & $\begin{array}{l}-0.238 \\
(0.119)\end{array}$ & $\begin{array}{l}-0.237 \\
(0.121)\end{array}$ & $\begin{array}{l}-0.262 \\
(0.123)\end{array}$ & $\begin{array}{l}-0.261 \\
(0.124)\end{array}$ & $\begin{array}{l}-0.317 \\
(0.127)\end{array}$ & $\begin{array}{l}-0.327 \\
(0.128)\end{array}$ \\
\hline $\begin{array}{l}\text { Several adults with } \\
\text { children }\end{array}$ & --- & $\begin{array}{l}--- \\
---\end{array}$ & $\begin{array}{l}-0.045 \\
(0.103)\end{array}$ & $\begin{array}{l}-0.045 \\
(0.104)\end{array}$ & $\begin{array}{l}-0.016 \\
(0.109)\end{array}$ & $\begin{array}{l}-0.015 \\
(0.110)\end{array}$ & $\begin{array}{c}0.048 \\
(0.122)\end{array}$ & $\begin{array}{c}0.048 \\
(0.121)\end{array}$ \\
\hline Not married & --- & $\begin{array}{l}--- \\
---\end{array}$ & $\begin{array}{c}0.264 \\
(0.079)\end{array}$ & $\begin{array}{c}0.265 \\
(0.080)\end{array}$ & $\begin{array}{c}0.305 \\
(0.081)\end{array}$ & $\begin{array}{c}0.306 \\
(0.083)\end{array}$ & $\begin{array}{c}0.333 \\
(0.085)\end{array}$ & $\begin{array}{c}0.339 \\
(0.084)\end{array}$ \\
\hline Male head & --- & --- & $\begin{array}{l}-0.083 \\
(0.060)\end{array}$ & $\begin{array}{l}-0.083 \\
(0.060)\end{array}$ & $\begin{array}{l}-0.052 \\
(0.063)\end{array}$ & $\begin{array}{l}-0.052 \\
(0.063)\end{array}$ & $\begin{array}{l}-0.017 \\
(0.065)\end{array}$ & $\begin{array}{l}-0.017 \\
(0.064)\end{array}$ \\
\hline Age of head & --- & $\begin{array}{l}--- \\
---\end{array}$ & --- & $\begin{array}{l}--- \\
---\end{array}$ & $\begin{array}{c}0.016 \\
(0.010)\end{array}$ & $\begin{array}{c}0.016 \\
(0.010)\end{array}$ & $\begin{array}{c}0.022 \\
(0.010)\end{array}$ & $\begin{array}{c}0.022 \\
(0.010)\end{array}$ \\
\hline $\mathrm{Age}^{2}$ & --- & $\begin{array}{l}--- \\
---\end{array}$ & --- & $\begin{array}{l}--- \\
---\end{array}$ & $\begin{array}{r}-0.0001 \\
(.0001)\end{array}$ & $\begin{array}{c}-0.0001 \\
(.0001)\end{array}$ & $\begin{array}{c}-0.0002 \\
(.0001)\end{array}$ & $\begin{array}{c}-0.0002 \\
(.0001)\end{array}$ \\
\hline No secondary education & --- & $\begin{array}{l}--- \\
---\end{array}$ & --- & $\begin{array}{l}--- \\
---\end{array}$ & $\begin{array}{c}0.093 \\
(0.056)\end{array}$ & $\begin{array}{c}0.093 \\
(0.057)\end{array}$ & $\begin{array}{c}0.038 \\
(0.062)\end{array}$ & $\begin{array}{c}0.036 \\
(0.062)\end{array}$ \\
\hline Post secondary education & $\begin{array}{l}--- \\
---\end{array}$ & $\begin{array}{l}--- \\
---\end{array}$ & $\begin{array}{l}--- \\
---\end{array}$ & $\begin{array}{l}--- \\
---\end{array}$ & $\begin{array}{c}0.111 \\
(0.104)\end{array}$ & $\begin{array}{c}0.111 \\
(0.104)\end{array}$ & $\begin{array}{l}-0.119 \\
(0.109)\end{array}$ & $\begin{array}{l}-0.120 \\
(0.109)\end{array}$ \\
\hline North & $\begin{array}{l}--- \\
---\end{array}$ & $\begin{array}{l}--- \\
---\end{array}$ & --- & $\begin{array}{l}--- \\
---\end{array}$ & $\begin{array}{l}--- \\
---\end{array}$ & $\begin{array}{l}--- \\
---\end{array}$ & $\begin{array}{c}0.073 \\
(0.079)\end{array}$ & $\begin{array}{c}0.072 \\
(0.078)\end{array}$ \\
\hline East & --- & $\begin{array}{l}--- \\
---\end{array}$ & $\begin{array}{l}--- \\
---\end{array}$ & --- & --- & $\begin{array}{l}--- \\
---\end{array}$ & $\begin{array}{l}-0.145 \\
(0.091)\end{array}$ & $\begin{array}{l}-0.142 \\
(0.090)\end{array}$ \\
\hline West & $\begin{array}{l}--- \\
---\end{array}$ & $\begin{array}{l}--- \\
---\end{array}$ & $\begin{array}{l}--- \\
---\end{array}$ & $\begin{array}{l}--- \\
---\end{array}$ & $\begin{array}{l}--- \\
---\end{array}$ & $\begin{array}{l}--- \\
---\end{array}$ & $\begin{array}{c}0.075 \\
(0.065)\end{array}$ & $\begin{array}{c}0.073 \\
(0.065)\end{array}$ \\
\hline Metropolitan area & --- & $\begin{array}{l}--- \\
---\end{array}$ & --- & --- & $\begin{array}{l}--- \\
---\end{array}$ & $\begin{array}{l}--- \\
---\end{array}$ & $\begin{array}{c}0.124 \\
(0.073)\end{array}$ & $\begin{array}{c}0.124 \\
(0.072)\end{array}$ \\
\hline Rural area & --- & $\begin{array}{l}--- \\
---\end{array}$ & $\begin{array}{l}--- \\
---\end{array}$ & --- & $\begin{array}{l}--- \\
---\end{array}$ & $\begin{array}{l}--- \\
---\end{array}$ & $\begin{array}{l}-0.060 \\
(0.059)\end{array}$ & $\begin{array}{l}-0.055 \\
(0.059)\end{array}$ \\
\hline Renting housing unit & --- & --- & $\begin{array}{l}--- \\
---\end{array}$ & $\begin{array}{l}--- \\
---\end{array}$ & --- & --- & $\begin{array}{c}0.071 \\
(0.103)\end{array}$ & $\begin{array}{c}0.070 \\
(0.102)\end{array}$ \\
\hline R-Squared $(n=365)$ & 0.019 & 0.020 & 0.134 & 0.134 & 0.150 & 0.150 & 0.197 & 0.198 \\
\hline
\end{tabular}

Source: SOEP 1996, Authors' calculations

Endnotes 


\begin{abstract}
${ }^{1}$ The immigration provisions of the 1996 law met with heavy criticism. Subsequent amendments to the law have restored some of the benefits; and states with large immigrant populations have maintained some programs and benefits at their own cost (Passell, Clark, and Fix, 1997).

${ }^{2}$ Other researchers also note the similarity in behavior of immigrants to different countries: For example, a comparative study of the economic status of immigrants in the two countries suggests that "United States immigrants look remarkably like German immigrants with few exceptions" (Frick, Smeeding, and Wagner, 1999, p. 21).
\end{abstract}

${ }^{3}$ The literature has also addressed other interesting questions that are not directly related to our main research objective, but on some of them we will also provide evidence. Many studies have shown interesting patterns of program participation across countries of origin and entry cohorts (e.g. Borjas and Hilton, 1996) and across reasons for immigration (especially asylum-seekers: see Voges, Frick, and Büchel, 1998). For a review of mainly labor market oriented literature concerning migration motivation, immigrant assimilation and the impact of immigration on the labor market see e.g. Zimmermann, 1995 and 1998. Zimmermann (1998) also stresses the necessity of considering national immigration policies, when evaluating immigration behavior: ,... immigration cannot per se be considered as good or bad for the labor market. Its impact on employment, wages and wealth depends crucially on the design of immigration policy,..

${ }^{4}$ A detailed description of the data and public-use access information for international scholars may be obtained in Wagner et al. (1993).

${ }^{5}$ There are some other means-tested programs. Certain forms of old-age pensions are available to people in circumstances of special need, and Wohngeld (housing subsidies) are based on annual family income. Although less important now than in years past, the system of Lastenausgleich (equalizing the burdens of WWII) has an explicit means-testing aspect, and some of the special programs designed to help East Germans after unification have been means-tested. On the whole, however, these programs are not very large compared to the SA system.

${ }^{6}$ The remaining 17.5 percent of the SA system's expenditures (not including expenditures on institutionalized clients - see Neuhäuser, 1996, p. 635) are made up by Hilfe in besonderen Lebenslagen (HBL). Under HBL, income assistance is provided for people in certain circumstances where some expenditure is considered necessary, but the expenditure is too high for the household's current income (see Bundesministerium für Arbeit und Sozialordnung, 1990, pp. 452ff). Thus, pregnant mothers may receive HBL assistance to obtain pre-natal care; disabled citizens may receive one-time help that allows integration into a certain workplace; if the main bread-winner of a household dies, temporary assistance may be given to some other household member to keep the household intact until new sources of income are found; temporarily homeless persons may be assisted with cash until some housing arrangement can be found; and persons with addictions or severe mental illness may be given one-time help to access temporary crisis services.

${ }^{7}$ Some HLU goes to people in institutions, where the payments are made directly to the institution and not to the individual. We do not have institutionalized people in our data, however, so for our purposes, HLU is basically a cash assistance system.

${ }^{8}$ There certainly are other countries with comparably clear-cut social assistance programs, such as the Income Support system in the UK and RMI (Revenue Minimal d'Insertion) in France. Although it is not clear that data exists on French immigrants, one might find some data on immigrants in the UK through the British Household Panel Survey. However, our data set, the German Socio-Economic Panel, has an ongoing immigration subsample designed to keep the overall sample representative of the current population of the country. See the next section.

${ }^{9}$ Using longitudinal SOEP-data from 1984 to 1996, Riphahn (1998) shows that attrition from the sample has an effect on estimates of immigrant participation in Social Assistance. Nevertheless, we decided to base our 
analysis on cross-sectional data from 1996 in order to control for recent immigrants to Germany who are not included in Riphahn's analysis; since 1996 is only the second wave of data on this population SOEP panel attrition is not a large concern. Riphahn also points out that one cannot control for unobserved heterogeneity with cross-sectional data. Further work using panel data is certainly warranted to address both issues, unobserved heterogeneity and differential attrition. We control for differential attrition only (see below).

${ }^{10}$ In detail these weights for 1996 are set up as follows: 0 through 7 years: $0.50 ; 8$ through 14 years: $0.65 ; 15$ through 18 years: $0.90 ; 19$ and over: 0.80 .

${ }^{11}$ In detail, these circumstances and their corresponding additional weights are as follows: Aged 65 and over: 20\%; Aged less than 65 but severely disabled: 20\%; Pregnant women: 20\%; Lone parent with 1 child aged less than 7 years: $40 \%$; Lone parent with 2 or 3 children aged less than 16 years: $40 \%$; lone parent with 4 or more children aged less than 16 years: 60\%; Aged 15 and over and eligible for integration assistance for the disabled: $40 \%$.

${ }^{12}$ The needs thresholds are changed each year as of the first of July. Since the interviews are almost exclusively done in the first half of the year, and since the 1995 needs thresholds remained valid until the end of June of 1996, we are using the 1995 needs threshold in our simulations.

${ }^{13}$ To identify the housing costs need of a given household we use the actual housing costs, observed in the SOEP separately for tenants and owner-occupiers. We then apply a top-trimming to these costs given by the average housing costs of main tenants (rent plus costs for heating and warm water) broken down for East- and WestGermany (here also broken down by categories of community size). By this method - which is applied by the social assistance agencies also - we reduce the number of households which would otherwise be identified as eligible for HLU, just because they live in very expensive apartments or houses. In fact, a comparison of our (top-trimmed) housing costs with the official statistics on housing costs for households receiving housing assistance (Wohngeld) shows a very high degree of accordance.

${ }^{14}$ Detailed information about deductible expenditures can be obtained from the original statutes of law (BSHG, Bundes-Sozialhilfe-Gesetz); information on the algorithm used for our simulation is available from the authors upon request.

15 This deviates from the definition often used in the literature, according to which immigrant households have an immigrant head. We found, however, that households with mixed immigrant/native heads and spouses were very similar in conditions and behavior to all-native households, while all-immigrant households were distinct. Therefore we define 'immigrant households' as all-immigrant households.

${ }^{16}$ Results for the instrumenting regression can be found in table A1 in the appendix.

${ }^{17}$ This is a similar exercise to Borjas and Hilton (1996), Section III, in which they show that accounting for various individual characteristics reduces but does not eliminate the positive effect of immigrant status on welfare receipt.

18 Because this regression does not add new information to our analysis, we do not present a table with the results.

${ }^{19}$ Tables A2 and A3 explore the robustness of these findings to changes in empirical method. Table A2 repeats table 4 using logistic regression instead of probit regression. The pattern is unchanged: immigrant households are slightly more likely to claim benefits, when their characteristics are unaccounted for; when these characteristics are accounted for, however, the immigrant effect becomes negative. Table A3 employs the OLS linear probability model with the same conclusion. In all three models (probit, logit, OLS) the coefficients on income, family structure, and age are statistically significant, while the coefficients on immigrant status are not.

${ }^{20}$ We define as households with "other wealth" those households whose annual income from interest and dividends exceeds DM 500, households who are owner-occupiers, and those who received income from rent.

${ }^{21}$ The number of immigrant households with other wealth is vanishingly small, thus we refrain from any interpretation of the coefficient (-6.940). 